\title{
Geochemistry of soil in relation to air-borne geophysical data and bedrock geology in Hattfjelldal, northern Norway
}

\author{
Malin Andersson', Ola Anfin Eggen', Henning Jensen', Alexandros Stampolidis', \\ Terje Bjerkgård' \& Jan Sverre Sandstad'
}

\author{
${ }^{1}$ Norges geologiske undersøkelse, 7491 Trondheim, Norway \\ E-mail corresponding author (Malin Andersson): malin.andersson@ngu.no
}

\begin{abstract}
This study presents geochemical results for 954 samples of Quaternary sediment deposits (equivalent to soil C horizon samples) collected in the Hattfjelldal area, Nordland, Norway. The study was initiated to define potential for ore deposits and define the regional background values. The $<2$ $\mathrm{mm}$ fraction of the samples has been analysed for 53 elements (Ag, Al, As, Au, B, Ba, Be, Bi, Ca, Cd, Ce, Co, Cr, Cs, Cu, Fe, Ga, Ge, Hf, Hg, In, K, La, Li, Mg, Mn, Mo, Na, Nb, Ni, P, Pb, Pd, Pt, Rb, Re, S, Sb, Sc, Se, Sn, Sr, Ta, Te, Th, Ti, Tl, U, V, W, Y, Zn and Zr) following an aqua regia extraction. Several multi-element anomalies are present within the survey area, which have not been localised before. The most prominent of these lie in the Hattli area. A statistical comparison of the major tectonic unit show no prominent chemical differences. A principal factor analysis was performed on the data, which distinguishes areas and lithologies with common chemical signatures. Periglacial sediments demonstrate comparable results to samples of the C-horizon of soils developed on till, with the exception of some elements (Y, U, La, K and Cs) that appear to become enriched and some other elements that appear to be depleted ( $\mathrm{Hg}, \mathrm{Cr}, \mathrm{Cd}$ and $\mathrm{Ag}$ ) during the transformation processes of these sediments. Anomalies in magnetic data coincide with ultramafic bodies and potential minor mineral deposits. Electromagnetic data are related mainly to graphite-bearing phyllites. The radiometric data have been correlated with the geochemical results, showing a good correlation for Th. The Th, $\mathrm{U}$ and $\mathrm{K}$ ternary map also reveals particular lithologies, such as tonalite, within the Helgeland Nappe Complex
\end{abstract}

Keywords: soil geochemistry, geophysical data, bedrock, anomalies, Hattfjelldal, Norway

Electronic Supplement 1: Boxplots of all elements.

Received 3. July 2015 / Accepted 16. September 2015 / Published online 6. January 2016.

\section{Introduction}

In 2011, the Geological Survey of Norway (NGU) started the programme Mineral resources in North Norway (MINN) to enhance the geological information in the region and to further assess and study mineral resources of the three northernmost counties through targeted geochemical, geophysical and geological mapping (http://www.ngu.no/en/projects/minn). The first geochemical study reanalysed Quaternary sediment samples from the entire area of northern Norway, taken in a pre- vious study (Kjeldsen, 1987). The new regional-scale and low-density geochemical results (1 sample per $40 \mathrm{~km}^{2}$ ) indicated large-scale anomalies for a range of elements (Ag, As, Bi, Cd, Co, Cr, Cu, Fe, Hf, Mn, Ni, Pb, Sb, Te, Zr) in the Hattfjelldal area (Reimann et al., 2011).

A geochemical mapping project was therefore initiated to further define the potential for ore deposits within the Hattfjelldal area. Soil samples were collected, air dried, sieved to $<2 \mathrm{~mm}$ and analysed for 53 elements (Ag, $\mathrm{Al}$, $\mathrm{As}, \mathrm{Au}, \mathrm{B}, \mathrm{Ba}, \mathrm{Be}, \mathrm{Bi}, \mathrm{Ca}, \mathrm{Cd}, \mathrm{Ce}, \mathrm{Co}, \mathrm{Cr}, \mathrm{Cs}, \mathrm{Cu}, \mathrm{Fe}, \mathrm{Ga}, \mathrm{Ge}$, Hf, Hg, In, K, La, Li, Mg, Mn, Mo, Na, Nb, Ni, P, Pb, Pd, Pt,

Andersson, M., Eggen, O.A., Jensen, H., Stampolidis, A., Bjerkgård, T. \& Sandstad, J.S. 2015: Geochemistry of soil in relation to air-borne geophysical data and bedrock geology in Hattfjelldal, northern Norway. Norwegian Journal of Geology 95, 315-337. http://dx.doi.org/10.17850/njg95-3-04 
Rb, Re, S, Sb, Sc, Se, Sn, Sr, Ta, Te, Th, Ti, Tl, U, V, W, Y, Zn and $\mathrm{Zr}$ ) following an aqua regia extraction. Here, results will be discussed in relation to bedrock and Quaternary geology, geophysical data and known mineral deposits. In addition, periglacial sediments will be evaluated as sample media. The natural chemical background changes regionally with geology and with the different materials overlying the bedrock (Salminen \& Tarvainen, 1997; Reimann \& Melezhik, 2001; Reimann \& Garrett, 2005). The chemical background must be known for both mineral exploration and also environmental geochemical surveys (Albanese et al., 2006), in order to distinguish areas that display anomalies. Several different background regimes, or tectonic units, can be identified in the Hattfjelldal area. Several areas that display geochemical anomalies, where more detailed studies may be conducted, are also identified.

\section{Bedrock geology and mineralisation}

The bedrock geology of the Hattfjelldal area (Fig. 1) has been studied for over a century; initially, Corneliussen (1891), Oxaal (1911), Holmsen (1913) and Rekstad (1924) gradually developed our geological understanding, adding new bedrock units to the descriptions. Strand (1953, 1955) and Barkey (1977) distinguished the main bedrock units and divided the area into different bedrock complexes. The Hattfjelldal area was part of a large-scale tectonostratigraphic study by Stephens et al. (1985), who had earlier subdivided the Köli Nappe Complex (KNC) into three thrust units (Stephens, 1980). Dallmann (1987) studied the Köli nappes, while Stølen (1985) looked in more detail at the Krutådal area in order to gain a better understanding of the ultramafic bodies and their structural constraints. Together they combined the existing knowledge into the 1:50,000 Hattfjelldal bedrock map (Dallmann \& Stølen, 1994). Krutfjellet has also been studied in further detail (Mørk, 1979, 1985). All these investigations have contributed towards the regional 1:250,000 bedrock map (Gustavson, 1981).

The geology of the studied area consists of several nappes that were thrust from the west on top of the older Precambrian basement during the Caledonian orogeny; these nappes also extend into Sweden. The KNC was, in turn, overthrust from the west by the Helgeland Nappe Complex (HNC) (Fig. 1). The KNC comprises several thrust-sheets that are divided into three main units; Lower, Middle and Upper Køli nappes (Stephens et al., 1985). The boundaries between the units are not clearly defined in all areas, which is why NGU currently has a mapping project to gain a better understanding of this particular area. The Lower and Middle Köli nappes consist of greenschist, greenstone (amphibolite), phyllite (often graphitic) and felsic metavolcanites (quartz keratophyre). The Lower Köli Nappe in addition includes large ultramafic bodies (originally harzburgites) that display varying degrees of serpentinisation. There are sev- eral tens of mapped ultramafic bodies ranging in size from less than $100 \mathrm{~m}$ to several $\mathrm{km}$ in diameter (Fig. 1), the Hatten intrusion being the most spectacular example. The Upper Köli unit is a high-grade metamorphic unit consisting mainly of schists and gneisses of sedimentary origin which surrounds a Silurian (437 Ma; Mørk, 1979) gabbro intrusion, situated in the Krutfjellet area (Dallmann \& Stølen, 1994).

The HNC in the Hattfjelldal area comprises mediumgrade metamorphic rocks that have been divided into three units: 1) the Skinnfjellet unit-dominated by felsic intrusions (granite to quartz diorite) and metagabbro, 2) the Geittinden unit-comprising quartzite and various mica schists/gneisses, and 3) the Appfjellet unit-consisting of alternating dolomite marble, calcite marble and mica gneisses (Dallmann, 1994).

Several of the registered ore occurrences (NGU, 2015) within the area are of insignificant or unidentified importance. Information about the mineralisations occurring in the area includes known prospecting work by several prospecting companies from the $19^{\text {th }}$ century onwards as well as investigations carried out by the Geological Survey of Norway. Directly to the northwest of the study area lies the only significant deposit of the region, Bleikvassli, which is a closed $\mathrm{Pb}-\mathrm{Zn}$ mine that operated between 1957 and 1998. A number of small base metal and gold-rich showings are situated within the area between the KNC and the HNC (between the solid black and stippled red lines in Fig. 1). These mineralisations are mainly vein-type, disseminated metals occurring in quartz veins. The veins are commonly forming networks and typically oriented with their long dimension eastwest. Small, but partly very rich, base metal showings are situated northeast of Vågfjellet. These are especially rich in zinc and lead, but are also enriched in gold and silver. The showings are mainly hosted by metavolcanic rocks and are classified as volcanogenic massive sulphide (VMS) type occurrences. The investigated area lies partly within a metallogenic $\mathrm{Cu}-\mathrm{Zn}$ province that covers the Köli units from the Grong area in Nord-Trøndelag to the south, extending northwards into Sweden. Part of the Hattfjelldal area can be compared to the GrongStekenjokk $\mathrm{Cu}-\mathrm{Zn}$ metallogenic province (Eilu et al., 2009). Within this province a number of large mineral deposits are present: Joma, Skorovas, Stekenjokk-Levi (Sandstad \& Hallberg, 2012). The Norwegian part of this area has also been covered recently by a new geochemical survey (Reimann et al., 2015).

\section{Quaternary geology}

The Quaternary deposits of the Hattfjelldal area are shown in Fig. 2. Thin or thick till deposits cover a large part of the mapped area, mainly located at lower altitudes around Røssvatnet and within part of the eastern area towards the Swedish border. Weathered bedrock 


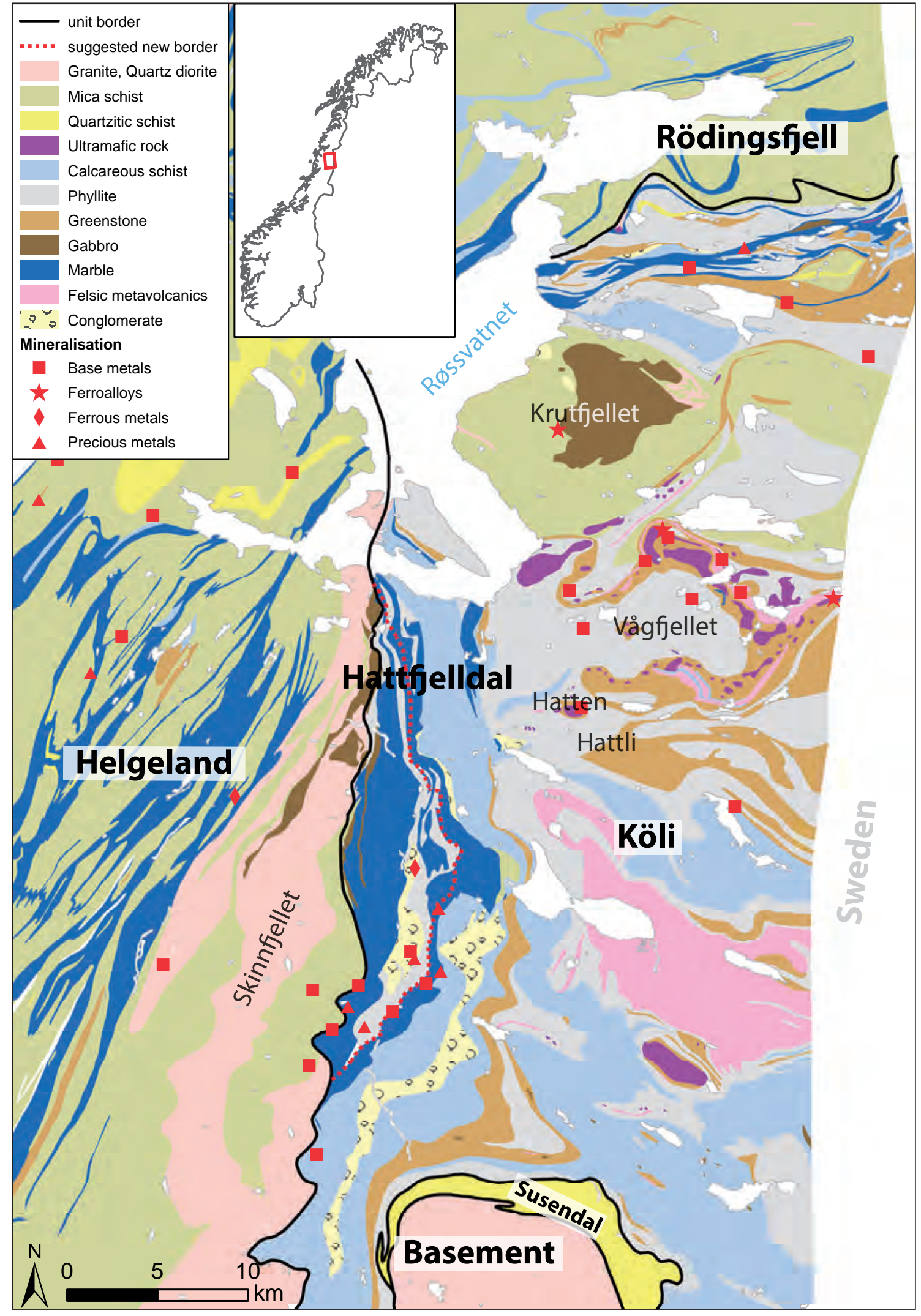

Figure 1. Bedrock geology of the sampled area and surroundings, based on Gustavson (1981). Names of bedrock units and nappe complexes discussed in text are in bold lettering. 


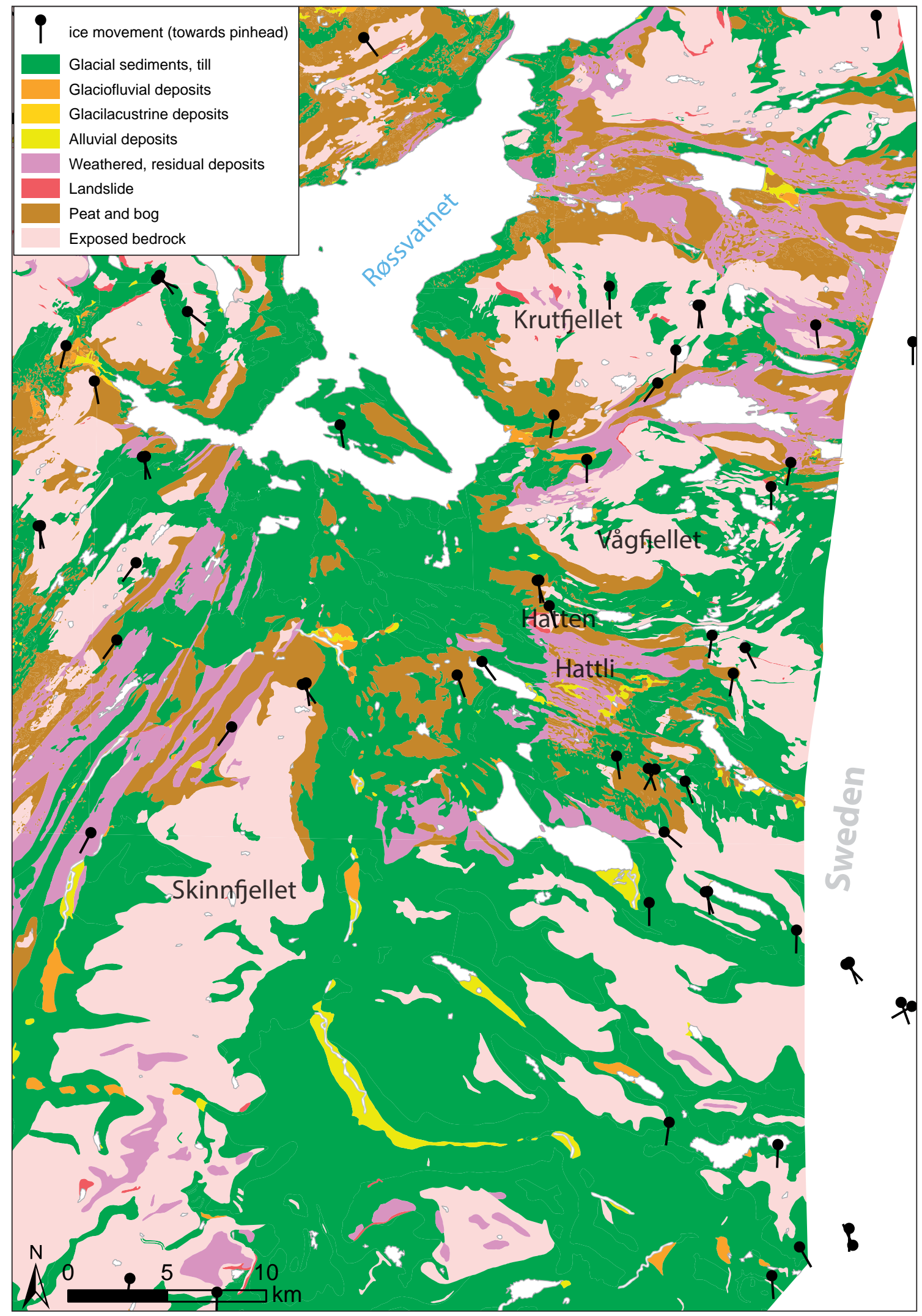

Figure 2. Quaternary geology of the sampled area. The dot (pinhead) of the ice movement symbol is placed on the observation location, the iceflow direction indicated towards the pinhead. 
is present mainly at higher altitudes, constituting thin Quaternary deposits. Such areas are present east of Røssvatnet, in the Skinnfjellet area and scattered throughout the southeastern part of the mapped area. Peat and bog mainly cover areas south of Hatten and east of Røssvatnet, indicating poor water drainage. Ice movement directions derived from observations in the field indicate northerly and northwesterly directions, and also northto northeasterly directions in the western part of the sampled area based on observations at approximately 40 locations (Bargel et al., 1999).

Well-sorted, fine-grained sediments that probably originated from processes within a periglacial environment (Anderson \& Anderson, 2010) were found at higher altitudes east of Røssvatnet and in the southeastern part of the mapped area. Within these areas, both till and weathered material have been subjected to periglacial processes, including frost and thaw, that have produced sediments that display a homogeneous colour and texture. This sediment type was previously established as a specific sample material by the geochemistry section at NGU. The areas where periglacial environments have been present lack the distinct podzol profile development.

Other types of sediments, such as glaciofluvial and fluvial deposits, have been sampled in six locations. These types of sediments were generally avoided as geochemical sample media because they consist of sediments that have potentially been transported further, originating from diverse and extensive areas, thus not representing the local types of bedrock.

The climate of the area is mostly temperate and humid with an average annual precipitation of $700-1000 \mathrm{~mm}$ that decreases to $500-700 \mathrm{~mm}$ near the Swedish border. The average yearly temperature is $0-2^{\circ} \mathrm{C}$, reducing to -2 $--4^{\circ} \mathrm{C}$ towards the border area. Temperature differences between summer and winter increase towards the eastern inland areas and the entire area is part of the boreal vegetation zone (Moen, 1998).

\section{Methods}

All samples were taken in a $1 \times 2 \mathrm{~km}$ grid, thus the resulting sampling density is one site per $2 \mathrm{~km}^{2}$. The total sampled area covers approximately $1900 \mathrm{~km}^{2}$, and a total of 954 localities were sampled. 879 samples were collected on foot while 75 samples, in less accessible areas, were collected using helicopter transport. Sampled media and approximate depth were registered for the first-mentioned samples, whereas the samples taken with helicopter support have more limited information. The sampled media was preferably till, where C-horizon material is considered to represent the unaltered and unweathered parent material (Fig. 3A). In areas where no till was pres-
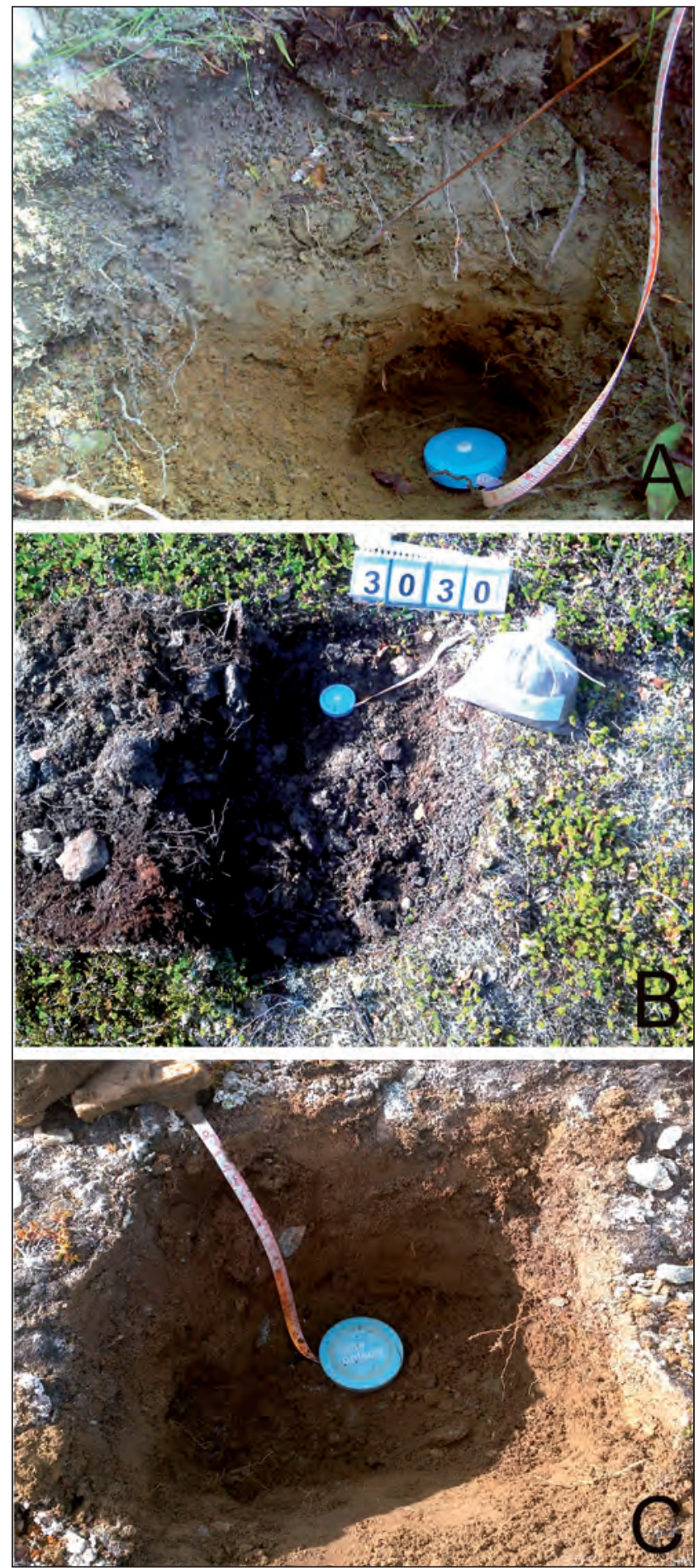

Figure 3. Typical sampled material. (A) Till, (B) weathered material, (C) periglacial sediments.

ent, sedentary soil was sampled, from here on referred to as weathered material (Fig. 3B). In the sample locations where signs of a periglacial environment are present, the sampled material is hereafter referred to as periglacial sediments (Fig. 3C). The majority of samples were identified either as till $(\mathrm{N}=681)$ or as weathered bedrock $(\mathrm{N}=167)$, and 131 samples were identified as periglacial sediments. A number of samples collected by heli- 
copter remain unidentified. All samples were assumed not to have been transported considerable distances, as both fluvial and glaciofluvial deposits were deliberately avoided.

All samples were taken from a depth that at each sample location represented as unaffected material as possible, therefore a close relationship between the parent material and the derived soils is to be expected. The decision for choosing sampling locations was based on existing Quaternary deposit maps and observations in the field. Sample pits were dug with a steel spade, stripped of paint. The samples were collected in Rilsan-bags. The average sample size was $1.6 \mathrm{~kg}$, wet weight. For approximately every $20^{\text {th }}$ sample a field duplicate was collected. A total of 49 duplicate pairs were taken. The duplicate samples were taken 1-10 $\mathrm{m}$ apart from the original sample at the same depth.

The samples were dried at temperatures below $40^{\circ} \mathrm{C}$ and subsequently dry sieved to $<2 \mathrm{~mm}$ using a nylon $2 \mathrm{~mm}$ sieve. The samples were sieved one at a time in a vented box. All sieving equipment was cleaned with a vacuum cleaner in between every sample. After sieving, the samples were randomised and control samples were inserted into the sample sequence. All samples were analysed at ACME labs, Vancouver, Canada. $15 \mathrm{~g}$ of sample material were digested in $90 \mathrm{ml}$ aqua regia (AR) and leached at $95^{\circ} \mathrm{C}$ for one hour in a water bath. After cooling, $5 \%$ $\mathrm{HCl}$ was added to produce a final $300 \mathrm{ml}$ volume. The samples were analysed using a Spectro Ciros Vision emission spectrometer (ICP-AES) and a Perkin Elmer Elan 6000/9000 inductively coupled plasma emission mass spectrometer (ICP-MS).

\section{Quality control}

In order to aid in the estimation of analytical precision and to calculate the practical detection limits, all instrument readings, independent of quantification and detection limits, were used in the subsequent calculations. Negative readings were replaced by a low positive value prior to some of the statistical analyses. Random plots were first used to study the quality of the data. Here, the data for a variable are plotted against its analytical sequence number. By including the median and deviation from the median it is possible to i) identify time trends or breaks in the analysis sequence, ii) to assess precision by looking at the spread from the median, and iii) get an impression of the accuracy if the 'true', certified value is known.

\section{Accuracy}

An inhouse project standard was used to estimate the accuracy of the analysis and to detect possible temporal trends or breaks in the analysis sequence in X-Charts. This standard material has also been used in previous regional geochemical studies (Reimann et al., 2012;
Finne \& Eggen, 2013) and therefore allows a comparison of an extensive amount of analyses of the standard. The laboratory also introduced a further 34 splits of its own, inhouse quality control (QC) samples DS10 and OSX109, and inserted them throughout the series for overall QC. The laboratory also replicated weighing, extraction and analyses of 33 replicates of ordinary samples throughout the analytical sequence.

\section{Precision}

Precision is estimated using the results of the analytical duplicates. In most cases, observed problems with precision were due to very low concentrations, where the analytical results are at or below the limit of quantification. This was observed for Au, B, Ge, Pd, Pt, Re, Se, Ta and Te. The practical detection limit (PDL) was established based on the method described by Demetriades (2011), using the results for analytical replicates. Good results of the duplicates led to usage of a lower PDL rather than the laboratory's method detection limit (MDL) for $\mathrm{Al}, \mathrm{Ca}, \mathrm{K}$, $\mathrm{Na}, \mathrm{S}$ and $\mathrm{Zr}$. On the other hand, PDL had to be increased for a range of elements; $\mathrm{Ag}, \mathrm{Au}, \mathrm{B}, \mathrm{Cd}, \mathrm{Co}, \mathrm{Hf}, \mathrm{Hg}, \mathrm{Mn}$, $\mathrm{Nb}, \mathrm{Ni}, \mathrm{Pb}, \mathrm{Pt}, \mathrm{Rb}, \mathrm{Re}, \mathrm{Se}$ and $\mathrm{Te}$.

According to the quality control results, the quality of the analyses of the elements $\mathrm{B}, \mathrm{Pd}, \mathrm{Pt}, \mathrm{Re}, \mathrm{Ta}$ and Te were too poor to be used. The results for $\mathrm{Au}, \mathrm{Cd}, \mathrm{Ga}, \mathrm{Hg}, \mathrm{In}, \mathrm{S}$, Se and $\mathrm{W}$ should be used with caution.

Extensive quality control analysis and results are documented by Eggen \& Finne (2014).

\section{Data analysis}

Geochemical data are compositional data, meaning that the variables are dependent on each other. Data are usually expressed as a percentage or parts per million and thus only represent relative information. The concentrations of all elements analysed depend on one another. Compositional data do not plot into Euclidean space but rather in the Aitchison geometry on the simplex. All statistical methods that are based on Euclidean distances (such as calculating the mean and the standard deviation or calculating a correlation matrix) may thus return incorrect results (Aitchison, 1986; Filzmoser et al., 2009). Special care should therefore be taken when analysing compositional data, as such data have some special properties which can lead to misleading results when applying the methods developed for classical statistical data analysis (Reimann et al., 2013). The raw data within this study have therefore been log-transformed before principal factor analysis or correlation analysis to obtain a more symmetric data distribution. EDA (exploratory data analysis) techniques and simple order statistics as suggested by Reimann et al. (2008) are used here. All statistical calculations are determined by use of the freely available R software (R Core Team, 2014) and the additional StatDA package (Filzmoser, 2013). Graphical tech- 
niques, such as box plots and factor analysis, have been used as suggested by Reimann et al. (2008).

\section{Principal factor analysis (PFA)}

There are several suggested guidelines on how to prepare a good PFA (for example, see Zhao, 2009 and references therein). As for the number of variables (elements) to include, we have followed a suggested rule of $n>p^{2}+3 p$ +1 (Le Maitre, 1982), where $n$ represents the number of samples and $\mathrm{p}$ the number of variables. With 954 samples this recommends including up to 29 variables in the PFA (Reimann et al., 2008). The elements selected for the factor analysis are $\mathrm{Ag}, \mathrm{Al}, \mathrm{As}, \mathrm{Bi}, \mathrm{Ce}, \mathrm{Co}, \mathrm{Cr}, \mathrm{Cu}, \mathrm{Fe}, \mathrm{Ga}, \mathrm{K}, \mathrm{La}$, $\mathrm{Mg}, \mathrm{Mn}, \mathrm{Na}, \mathrm{Nb}, \mathrm{Ni}, \mathrm{P}, \mathrm{Pb}, \mathrm{S}, \mathrm{Sb}, \mathrm{Sc}, \mathrm{Se}, \mathrm{Th}, \mathrm{Tl}, \mathrm{U}, \mathrm{V}, \mathrm{W}$ and $\mathrm{Zn}$. The data for this suite of elements were then controlled by calculating the Kaiser-Meyer-Olkin adequacy criteria (KMO) values, which is a useful approach when determining which elements provide enough signal to be used to evaluate geochemical processes. The calculations include the measurement of sampling adequacy (MSA) values (Kaiser \& Rice, 1974). All elements showed MSA values $>0.5$ and the overall KMO value was 0.76 , an adequacy that according to Hutcheson \& Sofroniou (1999) can be regarded as 'good'. To determine the optimal number of factors for the PFA, a scree plot was prepared for the log-transformed data. The scree plot determined that five factors are sufficient to visually inspect the main data structure. Robust procedures (Reimann et al., 2008) have been used in the computations to minimise the effect of outliers. A Varimax-rotation was applied to improve interpretability. The factor analysis is graphically presented as a loading plot where the $\mathrm{x}$-axis is scaled according to the explained variance for the whole dataset for each factor, and the $y$-axis is scaled from +1 to -1 and shows the factor loadings of the different variables entering each factor (Reimann et al., 2002). Only elements that have loadings $> \pm 0.3$ are shown in the loading plot as they represent the major contribution to the factor. The spatial distribution of the different factors can be presented as factor score maps.

\section{Multi-element anomaly analysis}

Visually studying the element maps, several areas — but also single locations - are distinguished by high concentrations for each element. In order to investigate whether geographical areas with high concentrations are shared between several elements, a multi-element plot was produced. The plot should demonstrate areas where several elements display anomalies.

The multi-element anomaly analysis plot illustrates results for each location where the element concentration is above the $75 \%$ concentration quantiles. Since all elements are not of interest to the same extent, the elements were divided into three classes, with different weightings based on their relative importance. The first class contains elements that were disregarded mainly because of analytical quality problems and levels generally below the detection limit ( $\mathrm{Au}, \mathrm{B}, \mathrm{Cd}, \mathrm{Hg}, \mathrm{Pd}, \mathrm{Pt}, \mathrm{Re}, \mathrm{Se}$, Ta and
Te). This class received zero weighting. The second class of elements (Al, Be, Ca, Ce, Cs, Ga, Ge, Hf, In, K, La, Mg, $\mathrm{Mn}, \mathrm{Na}, \mathrm{Sc}, \mathrm{Sr}, \mathrm{Y}$ and $\mathrm{Zr}$ ) received a weighting of 0.5 . The elements in the third class (Ag, As, $\mathrm{Ba}, \mathrm{Bi}, \mathrm{Co}, \mathrm{Cr}, \mathrm{Cu}$, Fe, Li, Mo, Nb, Ni, P, Pb, Rb, S, Sb, Sn, Th, Ti, Tl, U, V, W and $\mathrm{Zn}$ ) are of special interest for mineral exploration and received a weighting of 1 . The plot summarises the weighting of the elements for each location with the dots growing darker and bigger the more elements that are enriched at that particular location. Therefore, large dark dots indicate high-rating multi-element localities.

\section{Geophysics}

Through the airborne geophysical survey, high-resolution magnetic, electromagnetic and radiometric data were obtained over the study area. The survey (Rodionov et al., 2014) was conducted in order to improve our general understanding of the regional geology of the area.

The survey incorporated the use of a Hummingbird ${ }^{\mathrm{TM}}$ five-frequency electromagnetic system supplemented by a high-sensitivity caesium magnetometer and radar altimeter. The system was supplemented by a 1024 channel gamma ray spectrometer which was used to map ground concentrations of $\mathrm{U}$, Th and $\mathrm{K}$. The survey lines were spaced $200 \mathrm{~m}$ apart and the magnetic and electromagnetic sensors were maintained at an average of $56 \mathrm{~m}$ above the topographic surface. A GPS navigation computer system with flight path indicators ensured accurate positioning of the geophysical sensors with respect to the World Geodetic System 1984 geodetic datum (WGS-84). Instrument specifications and data processing information have been documented by Rodionov et al. (2014).

\section{Results and discussion}

The results for 48 elements that passed the quality control are presented in Table 1. Here, the concentration ranges and quantiles are presented. The median for the results for seven elements ( $\mathrm{Au}, \mathrm{Cd}, \mathrm{Ge}, \mathrm{In}, \mathrm{Se}, \mathrm{Te}$ and $\mathrm{W}$ ) were below the detection limit.

Geochemical maps for a selection of analysed elements are presented in Fig. 4. These particular elements were selected to illustrate the differences between the lithologies of the sampled area as well as in the registered mineralisations and main bedrock types.

The periglacial sediments as a sampling media have not been thoroughly assessed before. Therefore, in order to assess the quality of these media, a statistical comparison was carried out, where periglacial sediments were compared with till material that displayed podsol profiles (Fig. 5). The results show significant deviations between the two sample media for only a few elements. Periglacial 
Table 1. Geochemical results for all approved elements as well as practical detection limits (PDL). All results in $\mathrm{mg} / \mathrm{kg}$.

\begin{tabular}{|c|c|c|c|c|c|c|c|c|c|}
\hline & $n<P D L$ & $P D L$ & Min & Q5 & Q25 & Q50 & Q75 & Q95 & $\operatorname{Max}$ \\
\hline $\mathrm{Ag}$ & 46 & 0.005 & $<0.005$ & 0.005 & 0.014 & 0.025 & 0.047 & 0.13 & 0.65 \\
\hline $\mathrm{Al}$ & 0 & 50 & 64.5 & 4151 & 10739 & 13935 & 17019 & 24115 & 38640 \\
\hline As & 66 & 1 & $<1$ & $<1$ & 3.7 & 7.52 & 12 & 28 & 498 \\
\hline $\mathrm{Au}$ & 715 & 0.002 & $<0.002$ & $<0.002$ & $<0.002$ & $<0.002$ & 0.002 & 0.005 & 0.054 \\
\hline $\mathrm{Ba}$ & 1 & 0.5 & $<0.5$ & 6.2 & 12 & 17 & 25 & 54 & 262 \\
\hline $\mathrm{Be}$ & 163 & 0.1 & $<0.10$ & $<0.10$ & 0.14 & 0.23 & 0.34 & 0.61 & 1.7 \\
\hline $\mathrm{Bi}$ & 22 & 0.02 & $<0.02$ & 0.04 & 0.09 & 0.13 & 0.17 & 0.27 & 2.2 \\
\hline $\mathrm{Ca}$ & 4 & 50 & $<50$ & 256 & 936 & 1504 & 2058 & 3840 & 313558 \\
\hline $\mathrm{Cd}$ & 546 & 0.05 & $<0.05$ & $<0.05$ & $<0.05$ & $<0.05$ & 0.07 & 0.14 & 0.74 \\
\hline $\mathrm{Ce}$ & 0 & 0.1 & 1.1 & 7.5 & 21.7 & 37.1 & 52.0 & 88.8 & 225 \\
\hline Co & 20 & 0.4 & $<0.4$ & 2.1 & 7.2 & 11 & 16 & 26 & 69 \\
\hline $\mathrm{Cr}$ & 4 & 0.5 & $<0.5$ & 5.8 & 23 & 34 & 46 & 74 & 885 \\
\hline Cs & 4 & 0.02 & $<0.2$ & 0.4 & 0.8 & 1.1 & 1.6 & 2.9 & 9.8 \\
\hline $\mathrm{Cu}$ & 1 & 0.01 & $<0.01$ & 2.45 & 12.5 & 23.4 & 37.2 & 63.8 & 210 \\
\hline $\mathrm{Fe}$ & 0 & 100 & 177 & 8640 & 21518 & 27476 & 33076 & 51767 & 95312 \\
\hline $\mathrm{Ga}$ & 2 & 0.1 & $<0.10$ & 2.05 & 3.18 & 4.00 & 4.84 & 8.36 & 26.4 \\
\hline $\mathrm{Ge}$ & 786 & 0.1 & $<0.10$ & $<0.10$ & $<0.10$ & $<0.10$ & $<0.10$ & 0.16 & 0.31 \\
\hline $\mathrm{Hf}$ & 214 & 0.030 & $<0.030$ & $<0.030$ & 0.033 & 0.053 & 0.082 & 0.15 & 0.37 \\
\hline $\mathrm{Hg}$ & 185 & 0.010 & $<0.010$ & $<0.010$ & 0.011 & 0.018 & 0.027 & 0.045 & 0.23 \\
\hline In & 629 & 0.020 & $<0.020$ & $<0.020$ & $<0.020$ & $<0.020$ & 0.023 & 0.038 & 0.26 \\
\hline K & 4 & 25 & $<25$ & 222 & 430 & 663 & 1075 & 2475 & 10871 \\
\hline $\mathrm{La}$ & 2 & 0.5 & $<0.5$ & 3.0 & 7.9 & 14 & 22 & 37 & 128 \\
\hline $\mathrm{Li}$ & 4 & 0.10 & $<0.10$ & 2.2 & 8.8 & 12 & 16 & 23 & 73 \\
\hline $\mathrm{Mg}$ & 8 & 100 & $<100$ & 1068 & 4827 & 7204 & 9842 & 15166 & 85382 \\
\hline $\mathrm{Mn}$ & 10 & 10 & $<10$ & 57 & 194 & 335 & 518 & 941 & 5042 \\
\hline Mo & 3 & 0.01 & $<0.01$ & 0.14 & 0.33 & 0.54 & 0.90 & 2.4 & 18 \\
\hline $\mathrm{Na}$ & 91 & 5.0 & $<5.0$ & $<5.0$ & 19 & 32 & 49 & 92 & 626 \\
\hline $\mathrm{Nb}$ & 18 & 0.05 & $<0.05$ & 0.13 & 0.39 & 0.72 & 1.2 & 2.5 & 16 \\
\hline $\mathrm{Ni}$ & 4 & 0.3 & $<0.3$ & 3.3 & 15 & 25 & 37 & 62 & 364 \\
\hline $\mathrm{P}$ & 0 & 10 & 21 & 116 & 337 & 516 & 674 & 960 & 5187 \\
\hline $\mathrm{Pb}$ & 2 & 0.40 & $<0.40$ & 3.88 & 8.27 & 10.6 & 14.1 & 22.6 & 367 \\
\hline $\mathrm{Rb}$ & 7 & 0.5 & $<0.5$ & 2.6 & 5.7 & 8.5 & 13 & 25 & 68 \\
\hline S & 19 & 20 & $<20$ & 33 & 74 & 116 & 187 & 380 & 4353 \\
\hline $\mathrm{Sb}$ & 37 & 0.020 & $<0.020$ & 0.024 & 0.044 & 0.067 & 0.105 & 0.257 & 13.0 \\
\hline $\mathrm{Sc}$ & 2 & 0.1 & $<0.1$ & 0.7 & 2 & 2.4 & 3.1 & 4.8 & 17 \\
\hline $\mathrm{Se}$ & 736 & 0.5 & $<0.5$ & $<0.5$ & $<0.5$ & $<0.5$ & $<0.5$ & 0.9 & 6.0 \\
\hline $\mathrm{Sn}$ & 81 & 0.10 & $<0.10$ & $<0.10$ & 0.16 & 0.24 & 0.35 & 0.75 & 6.9 \\
\hline $\mathrm{Sr}$ & 2 & 0.5 & $<0.5$ & 2.2 & 5.4 & 8.3 & 11 & 23 & 252 \\
\hline $\mathrm{Te}$ & 834 & 0.07 & $<0.07$ & $<0.07$ & $<0.07$ & $<0.07$ & $<0.07$ & 0.097 & 0.49 \\
\hline Th & 2 & 0.1 & $<0.1$ & 0.9 & 3 & 4.3 & 6.1 & 9.8 & 15 \\
\hline $\mathrm{Ti}$ & 1 & 10 & $<10$ & 157 & 485 & 755 & 1087 & 2022 & 7213 \\
\hline $\mathrm{Tl}$ & 48 & 0.02 & $<0.02$ & $<0.02$ & 0.06 & 0.09 & 0.13 & 0.22 & 0.4 \\
\hline $\mathrm{U}$ & 4 & 0.1 & $<0.10$ & 0.25 & 0.55 & 0.82 & 1.1 & 2.7 & 20 \\
\hline $\mathrm{V}$ & 9 & 2 & $<2.0$ & 10 & 22 & 29 & 38 & 70 & 281 \\
\hline W & 629 & 0.05 & $<0.05$ & $<0.05$ & $<0.05$ & $<0.05$ & 0.06 & 0.17 & 2.0 \\
\hline $\mathrm{Y}$ & 0 & 0.01 & 0.21 & 1.7 & 3.9 & 5.8 & 8.1 & 16 & 92 \\
\hline $\mathrm{Zn}$ & 0 & 0.10 & 0.62 & 13.4 & 32.7 & 45.9 & 58.1 & 83.6 & 1335 \\
\hline $\mathrm{Zr}$ & 4 & 0.05 & $<0.05$ & 0.58 & 1.8 & 2.8 & 4.1 & 7.2 & 23 \\
\hline
\end{tabular}



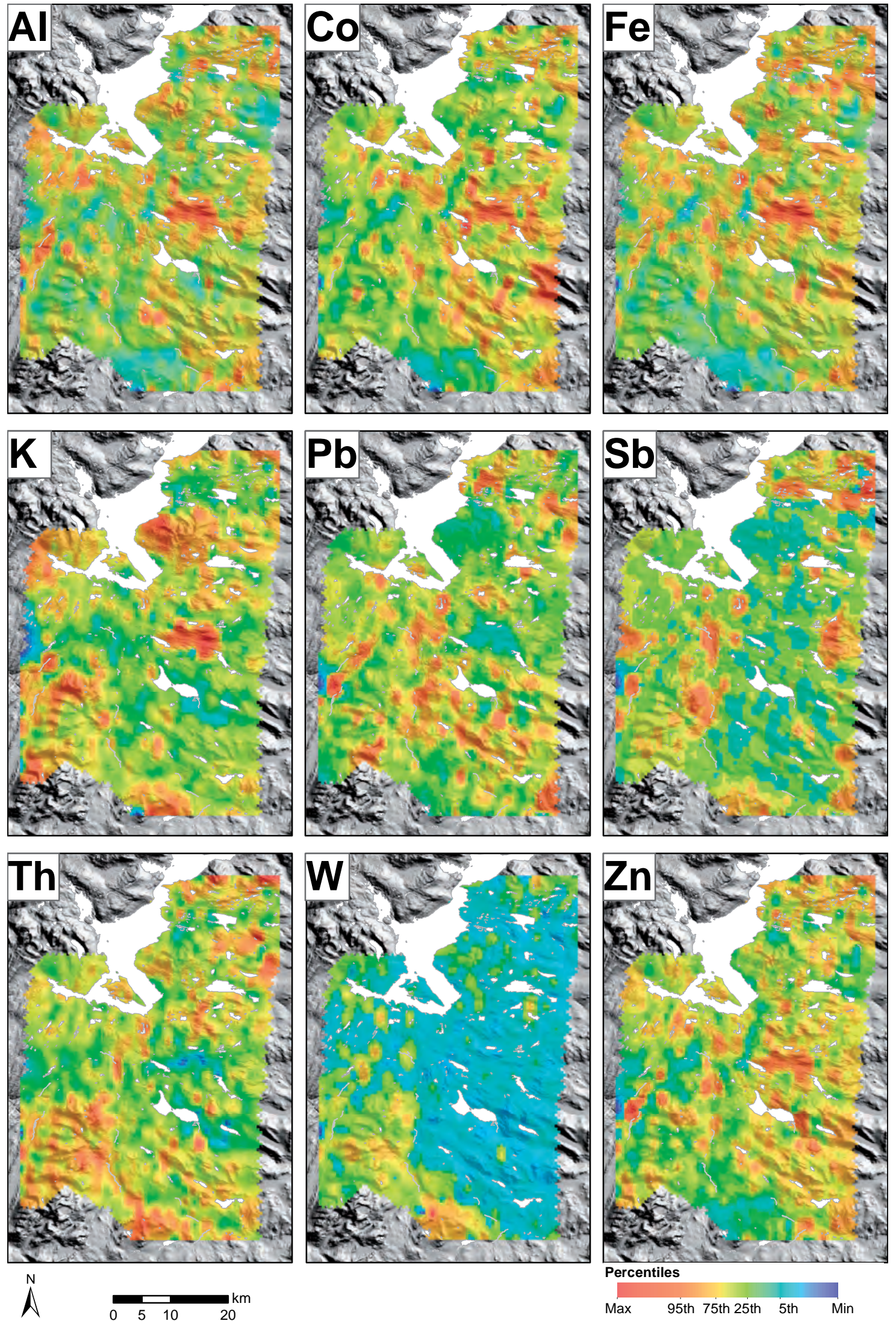

Figure 4. Geochemical results for selected elements. All results presented as concentration percentiles (Table 1).

sediments show significantly lower concentrations for $\mathrm{Hg}, \mathrm{Cr}, \mathrm{Cd}$ and $\mathrm{Ag}$ and appreciably higher concentrations for $\mathrm{Y}, \mathrm{U}, \mathrm{La}, \mathrm{K}$ and $\mathrm{Cs}$. Higher concentrations of the latter elements may, according to Grunsky et al. (2009), indicate that sediments have been subjected to reworking by different environmental processes such as erosion and 


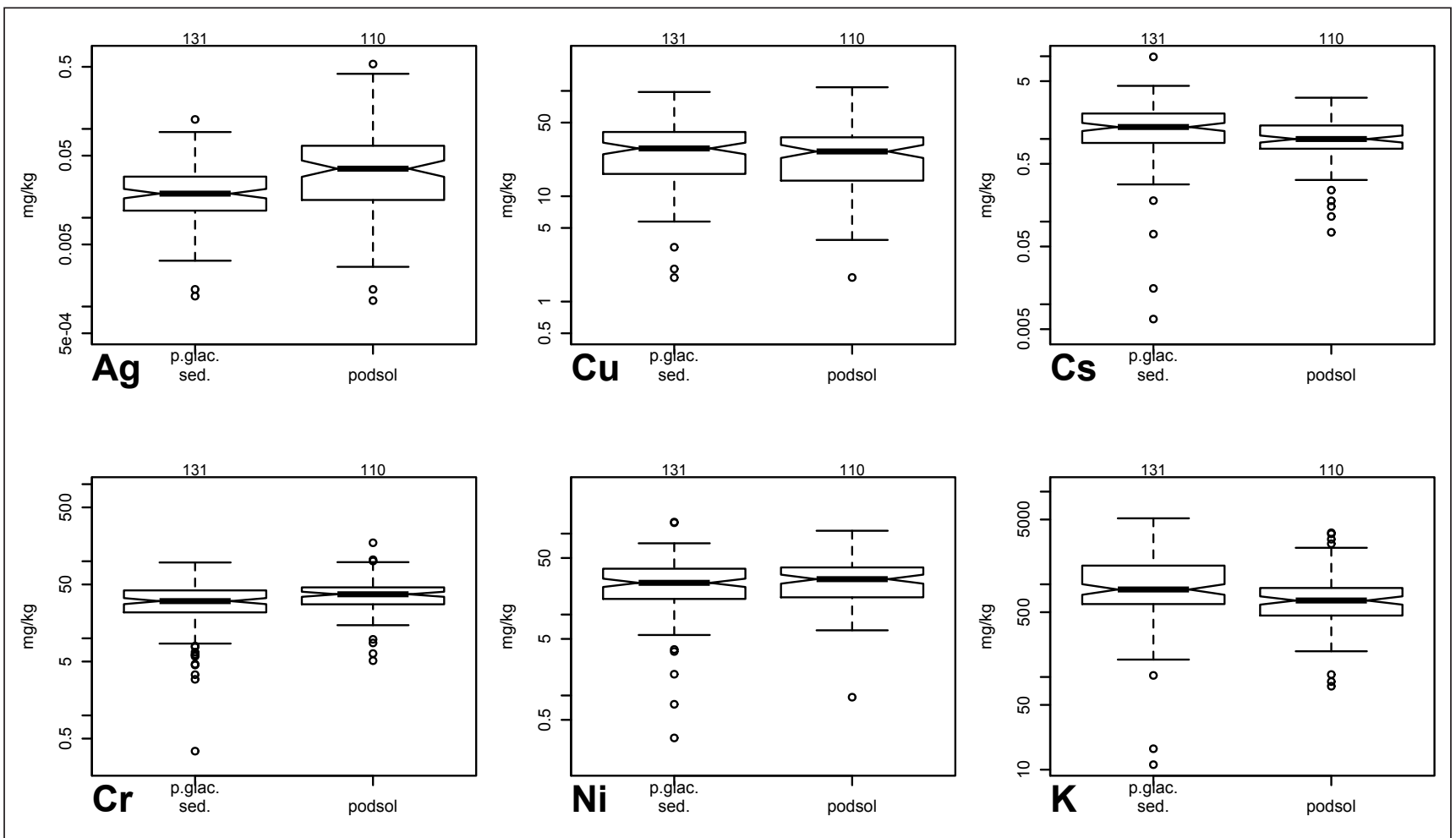

Figure 5. Boxplots of selected elements comparing analytical results of periglacial sediments (p.glac.sed.) and till material.

infiltration by fluids, as some minerals withstand weathering better than others. Still, on the whole, periglacial sediments can be considered a reliable sample medium in this type of geochemical mapping, as most elements display very similar concentration ranges for both sample media in a large-scale mapping study such as this one. As the differences between the different sampled materials are not significant in relation to the total variation, all data are presented together in the same maps.

\section{Geochemistry and main tectonic units}

It was of some interest within this study to investigate whether there were any differences in concentration levels between samples covering the different tectonic units. Fig. 1 presents the bedrock geology and main tectonic units based largely on the map by Gustavson (1981). In this comparison some minor adjustments were made to the location of the contact between the $\mathrm{HNC}$ and the KNC, positioning it farther towards the east. Thus, the number of samples included in the HNC was increased for this particular evaluation. The western border between the nappe complexes (solid black line in Fig. 1), as defined by Gustavson (1981), closely follows the eastern limit of high concentrations of thorium within the K-Th-U ternary map, which is presented in the section on radiometric data. Magnetic data, however, show continuing N-S lineaments also east of this contact. This N-S lineament trend stands in marked contrast to the Köli Nappe Complex, where the structural trend is mainly E-W. The new border (stippled red line in Fig. 1), in addition to using magnetic data, was drawn with the aid of the geochemical results for antimony; these results display a sudden concentration level difference when moving across the new contact, possibly indicating the presence of another bedrock unit.

All samples were grouped within the corresponding tectonic unit based on their geographical location. The analytical results corresponding to the main bedrock units are presented in Tukey boxplots (Fig. 6; Tukey, 1977).

A visual comparison was performed to evaluate whether significant differences exist between the concentration ranges of the main tectonic units. The comparison considers the vertical alignment of the middle notches within two boxplots which gives an indication of significant concentration differences between the elements that the boxplots represent. If the notches of two plots do not overlap, this is considered as 'strong evidence' that the two medians differ significantly (Chambers et al., 1983). Our comparison of the major tectonic units (Fig. 6 ), shows to a large degree that they are similar. The only major exceptions are significantly higher $\mathrm{Nb}$ and $\mathrm{Ti}$ in the HNC and low W in the KNC. Boxplots for all analysed elements are presented in Electronic Supplement 1.

Within the KNC, many elements such as $\mathrm{Al}, \mathrm{Ba}, \mathrm{Cr}$ and Fe display narrow interquartile ranges, indicating that the samples taken from within the complex have similar concentrations for these elements. A consequence of 

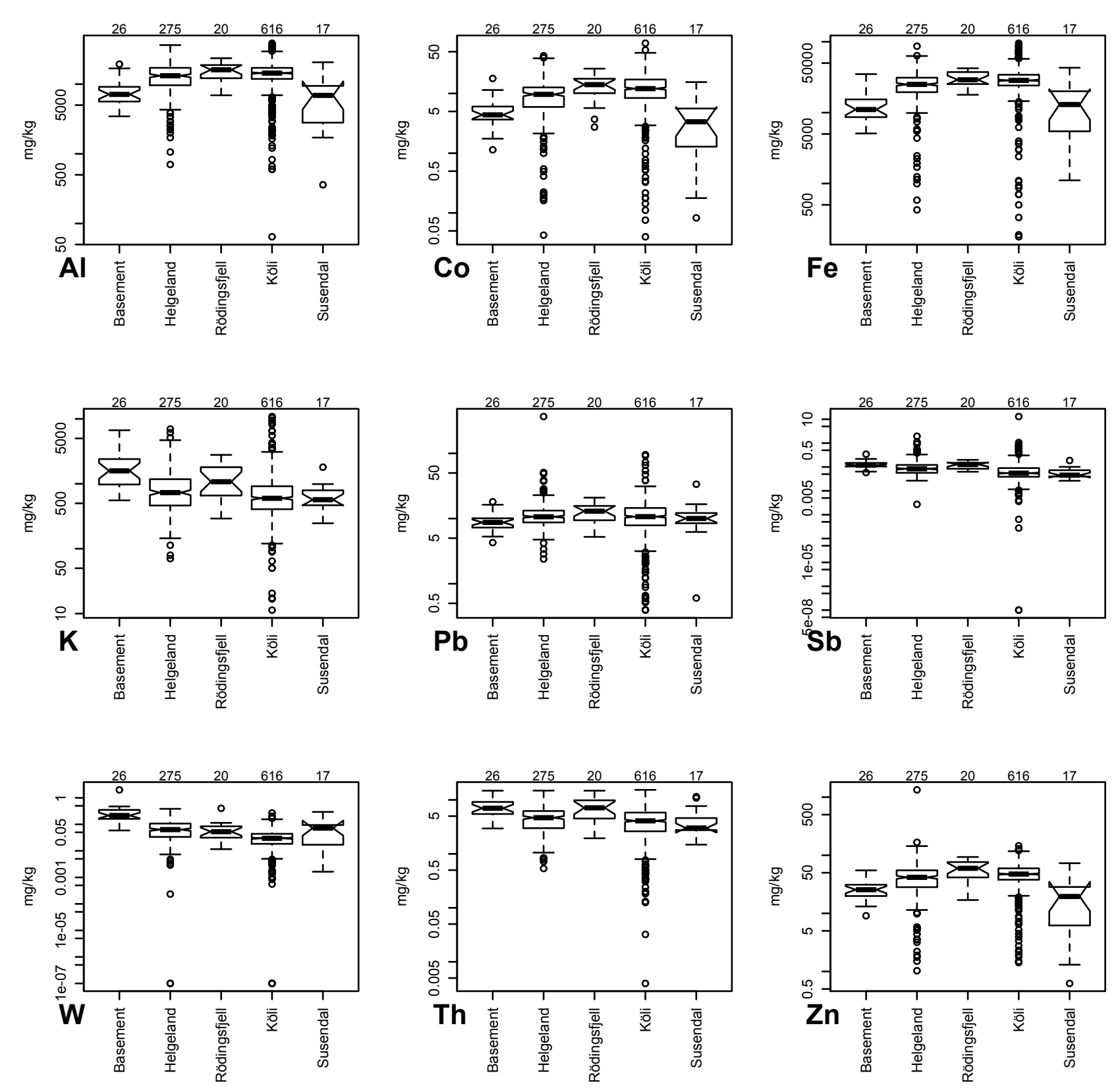

Figure 6. Analytical results for selected elements of samples that correspond to tectonic units, as divided within this study.

the narrow concentration ranges within the boxplots is a larger number of outliers as compared to boxplots for the other tectonic units.

Even though the KNC does not display concentration ranges that are significantly different from other units, one major geochemical anomaly, named Hattli, stands out in the dataset. The Hattli area is marked by a prominent multi-element anomaly covering a restricted area (approximate size $20 \mathrm{~km}^{2}$ ) that can be clearly distinguished in the $\mathrm{Al}, \mathrm{Co}, \mathrm{Fe}, \mathrm{K}$ and $\mathrm{Zn}$ maps (Fig. 4). A total of 21 sample locations are included in the Hattli anomaly (the count based on maps of $\mathrm{Al}$ and $\mathrm{Zn}$ ). The anomaly shows, in addition, high concentrations of $\mathrm{Ba}, \mathrm{Be}, \mathrm{Ca}, \mathrm{Ga}$, $\mathrm{Mg}, \mathrm{Mn}, \mathrm{P}, \mathrm{Rb}, \mathrm{Sr}, \mathrm{Ti}$ and $\mathrm{V}$ compared to the average for the KNC, but also compared to the entire sampled area (Fig. 7). The Hattli area also displays anomalously low concentrations of $\mathrm{Cs}, \mathrm{Pb}, \mathrm{U}, \mathrm{Th}, \mathrm{Zr}, \mathrm{Pb}$ and As.

According to the existing lithological map, the Hattli area consists of several different lithologies, including greenstone, mica schist and phyllite. The lithologies mapped in the anomaly area are not easily verified as they are covered either by thick deposits of overburden or by bog, and the Quaternary geological map (Fig. 2) characterises the area as affected by weathering. Whether this has influenced the chemical composition of the overlying deposits by some weathering process has not been verified. 


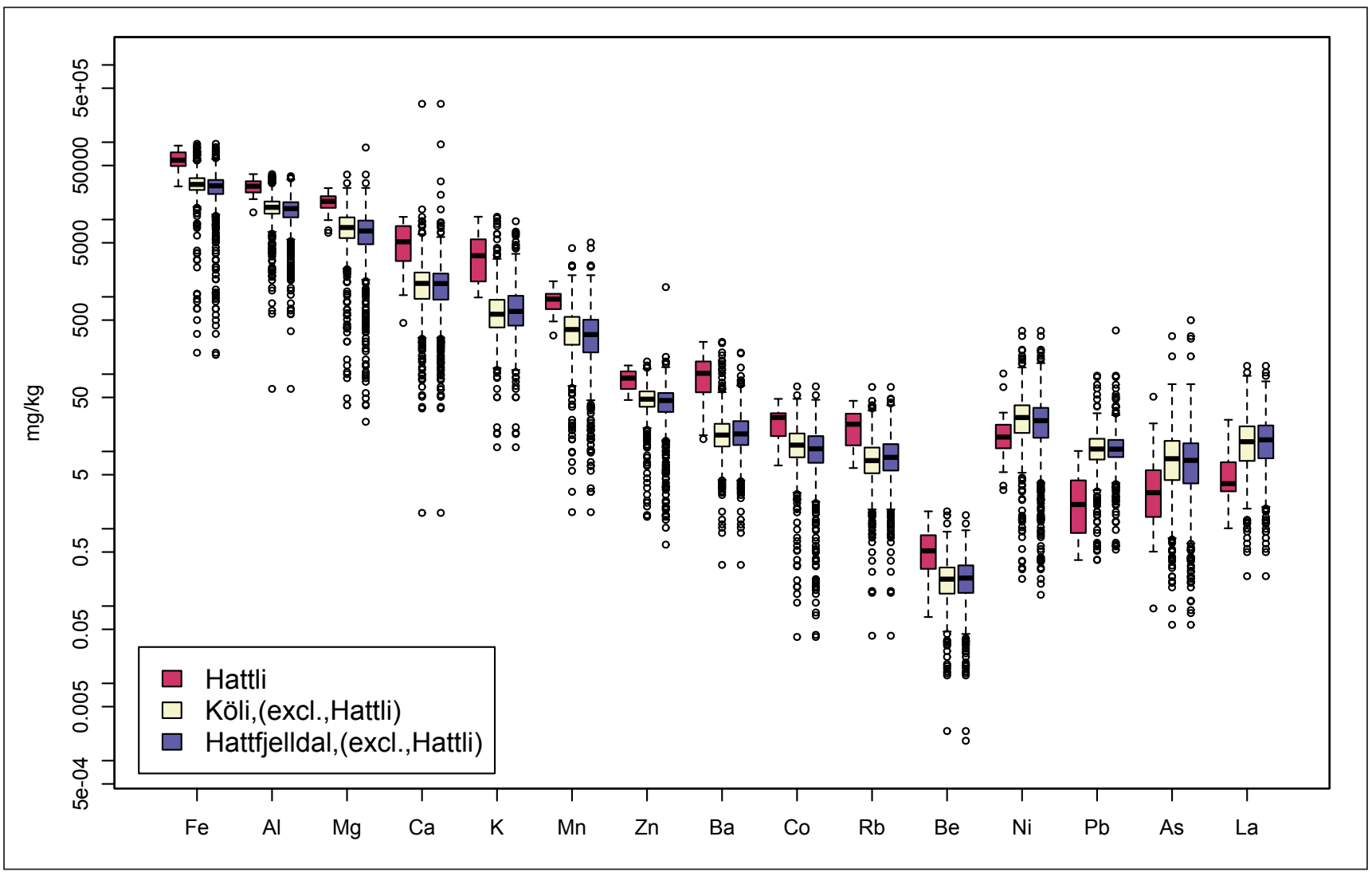

Figure 7. Analytical results for selected elements comparing samples within the Hattli anomaly area with the KNC and the entire area.

The Børgefjell basement window (Basement unit; Fig. 1) consists of largely of granitic gneisses and is located in the southernmost part of the study area. The results for the samples taken within this unit display significantly higher concentrations of $\mathrm{Hf}, \mathrm{Rb}, \mathrm{U}, \mathrm{W}$ and $\mathrm{Zr}$, and markedly lower concentration ranges of $\mathrm{Hg}$ and $\mathrm{S}$ compared to the other major tectonic units.

The samples from the Rödingsfjället Nappe Complex (RNC) in the northeast display significantly higher concentrations of As, Be, Ce, $\mathrm{Y}$ and $\mathrm{Zn}$ compared to the other units. The basement and the RNC both show high concentrations of $\mathrm{Cs}, \mathrm{K}, \mathrm{Rb}, \mathrm{Sb}, \mathrm{Th}, \mathrm{U}$ and $\mathrm{Tl}$. The high concentrations of these elements within the Rödingsfjället unit cannot be explained by the existing bedrock map, if due to granitic rocks. However, a large unit of granitic gneiss has recently been mapped (O. Lutro, pers. comm., 2015) in the RNC close to the Köli border, which may explain these chemical similarities. This granitic gneiss is evident on the 1:50,000 bedrock map 'Røssvatnet' (Gjelle et al., 2003).

The Susendal Nappe surrounds the Børgefjell basement and consists mainly of quartzitic schist. The samples from this narrow unit show significantly lower concentration ranges for $\mathrm{Au}, \mathrm{Ca}, \mathrm{Ce}, \mathrm{La}, \mathrm{Li}, \mathrm{Na}, \mathrm{P}, \mathrm{Sr}$ and $\mathrm{Th}$, when compared to the other bedrock units. The basement and Susendal units are comparable with respect to elements with relatively low concentrations, including
$\mathrm{Al}, \mathrm{As}, \mathrm{Co}, \mathrm{Cr}, \mathrm{Cu}, \mathrm{Fe}, \mathrm{Ga}, \mathrm{In}, \mathrm{Mg}, \mathrm{Mn}, \mathrm{Ni}, \mathrm{Sc}, \mathrm{V}$ and $\mathrm{Zn}$. This is evident even though the units comprise different lithologies, the basement consisting of granitic rocks and the Susendal unit quartzitic schist. These chemical similarities might be due to the fact that they are geographically close to each other, and that consequently the Quaternary deposits overlying the different bedrock types could be of a mixed character.

Within the upper Köli unit, an area that includes the mountain Krutfjellet and surroundings (the Krutfjellet Group), the lithologies consist mainly of mica schists and gneisses, conglomerates and amphibolites. The Krutfjellet Group has been intruded by the Krutfjellet intrusive complex, which mainly comprises a gabbro intrusion with minor areas of diorite and granite (Mørk, $1979,1985)$. Here, the chemistry of the overlying soil is characterised by high concentrations of $\mathrm{Na}, \mathrm{K}, \mathrm{Rb}$ and $\mathrm{Ti}$. This group of soil samples also displays low concentrations of $\mathrm{Mn}, \mathrm{Pb}$ and $\mathrm{Sb}$.

There is a low correlation between soil geochemistry and known mineral deposits. The mineral deposits within the sampled area are small (most classified as insignificant in the ore database) whereas the soil has been sampled using only a low-density grid. Therefore, it is not surprising that the deposits do not show up more clearly on the geochemical maps. 


\section{Principal factor analysis (PFA)}

PFA was carried out on the data to detect any hidden multivariate data structures that otherwise could remain undetected. PFA is based on the correlation structure of the variables and the common factors do not explain the total variation of the data. This implies that factor analysis allows for the existence of some unique factors that have a completely different behaviour than the majority of all other factors. Thus, unusual variables will not enter the common factors, in contrast to principal component analyses (PCA). The 'factor' is interpreted as representing processes controlling the chemistry that explain how elements potentially occur and interact (Reimann et al., 2002). Several methods within factor analysis have been tested out and tried for this dataset. The variations include alternating the number of elements, the type of data transformation, the number of factors, and the use of covariance matrix and rotation. The results discussed here reflect the common features of these different approaches.

Results for the PFA are displayed as load plots in Fig. 8 and factor score maps in Fig. 9. The PFA ranks elements in relation to how important their contribution is to the factor as 'factor loadings'. The higher the loading (the higher up or lower down in the plot they are situated), the more influential the elements are to the factor. The model with five factors explains $66 \%$ of the total data variability. Factors 3 and 4 are both positively and negatively influenced by the variables. Factor 1 is interpreted to display an association of geogenic elements that represent the chemical characteristics of ultramafic rocks, such as $\mathrm{Co}, \mathrm{Cr}, \mathrm{Cu}$,
Fe, Mg, Mn, Ni, Sc and V (Goldhaber et al., 2009), even though the area where ultramafic bodies are exposed is not clearly reflected in the element maps for these elements. This is not completely unexpected as the ultramafic bodies are small and the sampling grid is widely spaced. Also, ultramafics have limited soil development, therefore sampling was not possible to perform directly on top of the bodies. The factor also emphasises the elements that display anomalies within the Hattli area. In addition, Factor 1 shows an element group that might represent minerals occurring within greenstone: $\mathrm{Mg}, \mathrm{Al}, \mathrm{Fe}, \mathrm{Mn}, \mathrm{Ni}$, $\mathrm{Cu}$ and $\mathrm{Zn}$. This is partly in agreement with Ellefsen et al. (2014), where many of the elements in Factor 1 were enriched in areas associated with shale, clay- and mudstone. Factor 1 is represented over a large area covering the ultramafic bodies, greenstone, phyllites and metavolcanic rocks (Fig. 9). Factor 2 potentially represents elements characteristic for granites. Factors 2 and 3 are present in the factor score maps (Fig. 9) in similar geographical areas. In addition to indicating the basement granite, an Ordovician granite suite of the Helgeland Nappe Complex is also emphasised. The granites are exposed on Skinnfjellet and the occurrence of Th is also discussed below in the section on radiometric data. Factor 4 may be related to ongoing weathering processes and to specific lithologies within the upper Köli unit in the Krutfjellet area. The variables that have a positive loading within the factor represent elements that are absent, or present in low concentrations, within the areas that show anomalies for $\mathrm{Na}$ and $\mathrm{K}$. These two elements have a negative loading within the factor. Factor 5 potentially represents elements characteristic for massive sulphide deposits.

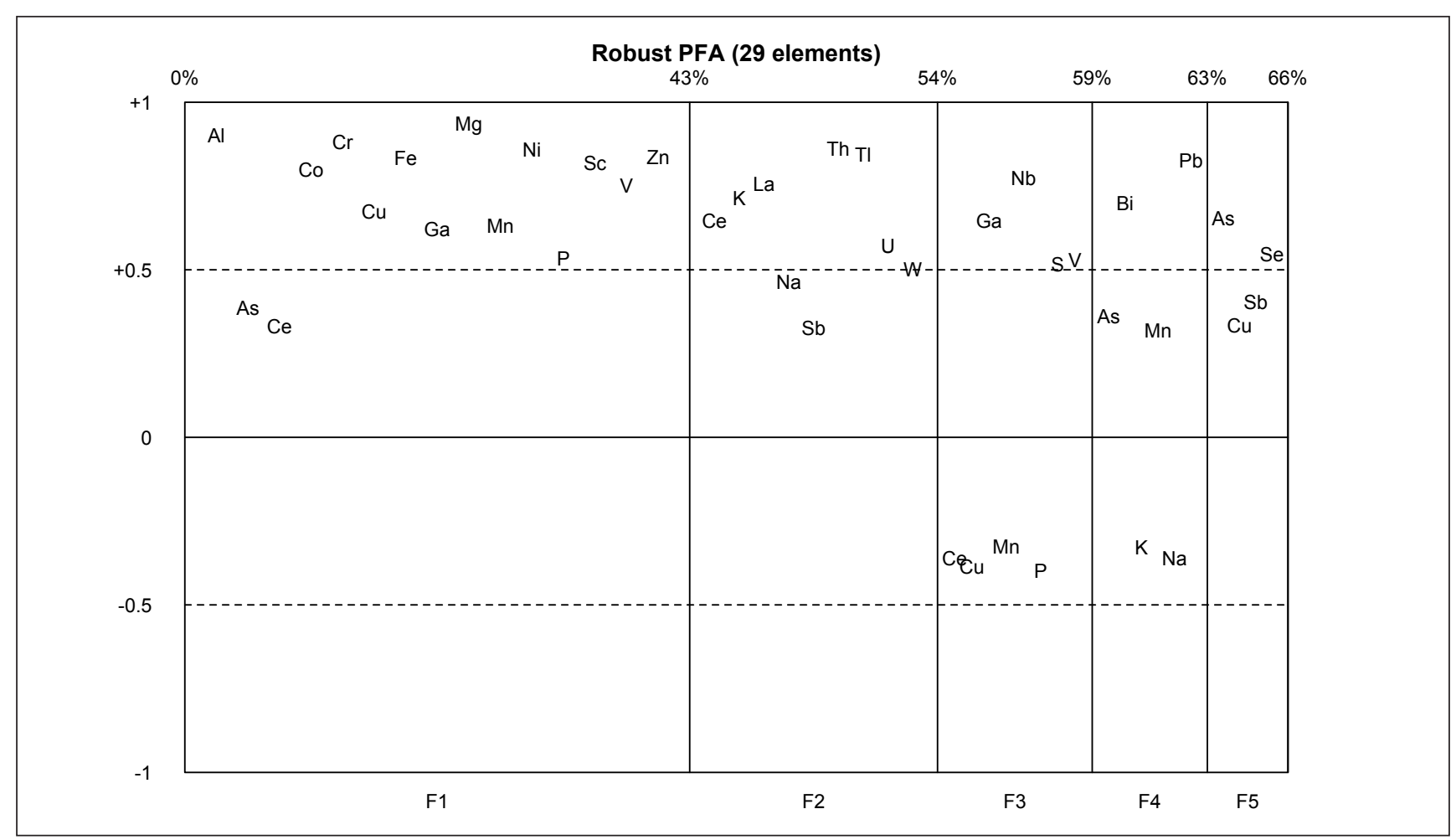

Figure 8. Principal factor analysis (PFA) plot for all samples, using robust procedures and including 29 elements. 


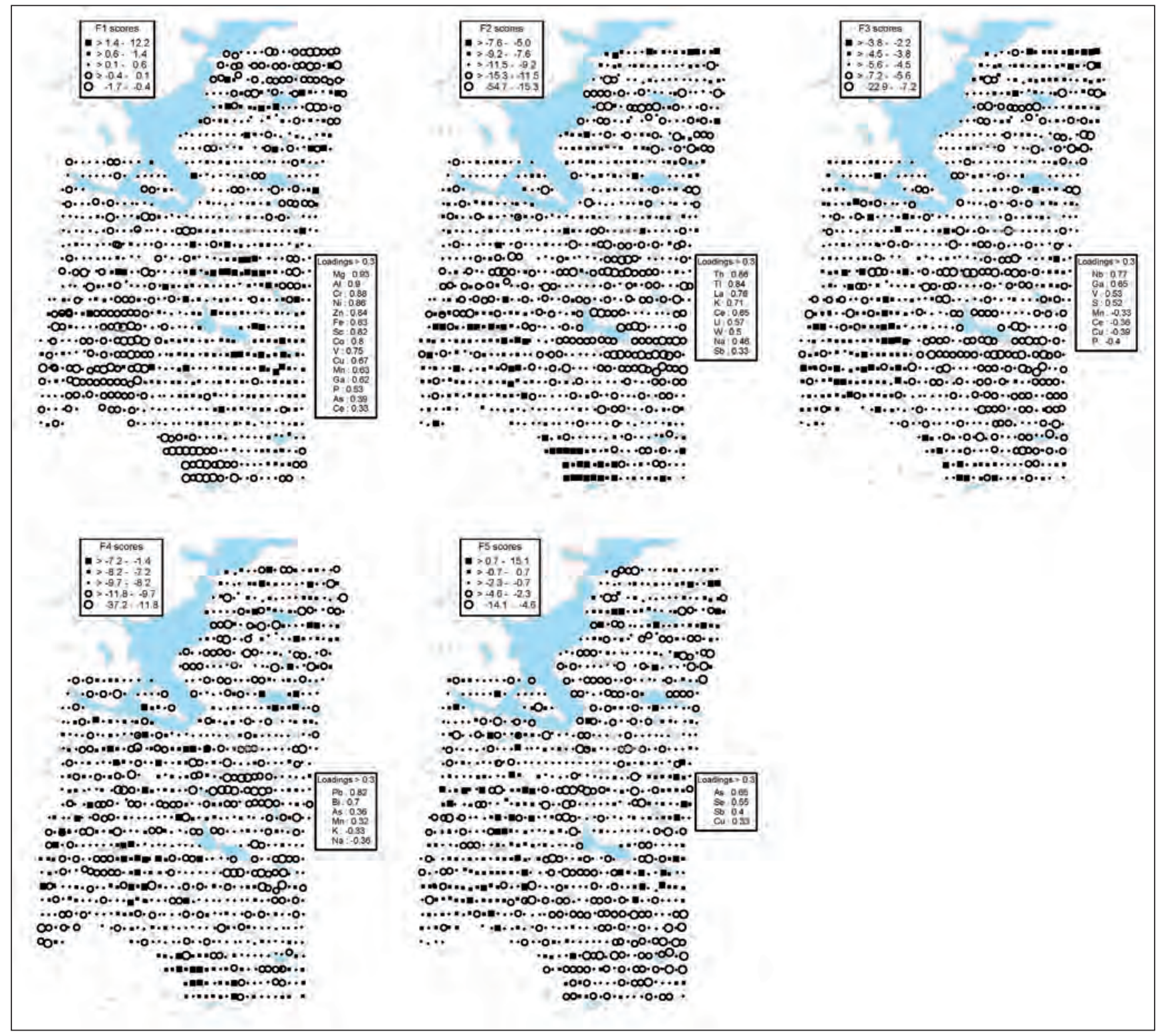

Figure 9. Factor score maps for the PFA in Fig. 8.

\section{Multi-element anomaly analysis}

While the purpose of the PFA is to display the broad outline of a dataset, the multi-element plot presents an element analysis for each location, where the highest concentrations of each element have been summarised (Fig. 10). The most prominent feature on the plot is, as expected, the Hattli anomaly (A), as a whole group of elements display high concentrations in that area. Another two features that stand out from the data analysis is an elongated anomaly which is situated in the border area between the quartz diorite of Skinnfjellet and the area west of it that consists of marble and mica schist (B), as well as an area southwest of Røssvatnet (C). Finally, in the northeastern corner of the study area, an anomaly which is more scattered stands because of its high concentrations of $\mathrm{S}, \mathrm{Zr}$ and $\mathrm{Sb}(\mathrm{D})$. When an Al-normalisation was performed on the data, this particular anomaly became especially pronounced. In contrast, the Hattli anomaly became weaker during the normalisation, which could indicate that this particular anomaly might be associated with some kind of weathering process.

\section{Geophysical data}

Within the Hattfjelldal area, the airborne geophysical survey resulted in maps presenting distributions of magnetic, electromagnetic and radiometric anomalies. In this study, data for these results will be discussed in relation to the geochemical data and lithologies. Table 2 summarises the geophysical signatures of the various formations mapped in the Hattfjelldal area.

Magnetic data

Aeromagnetic surveys map variations in the local 


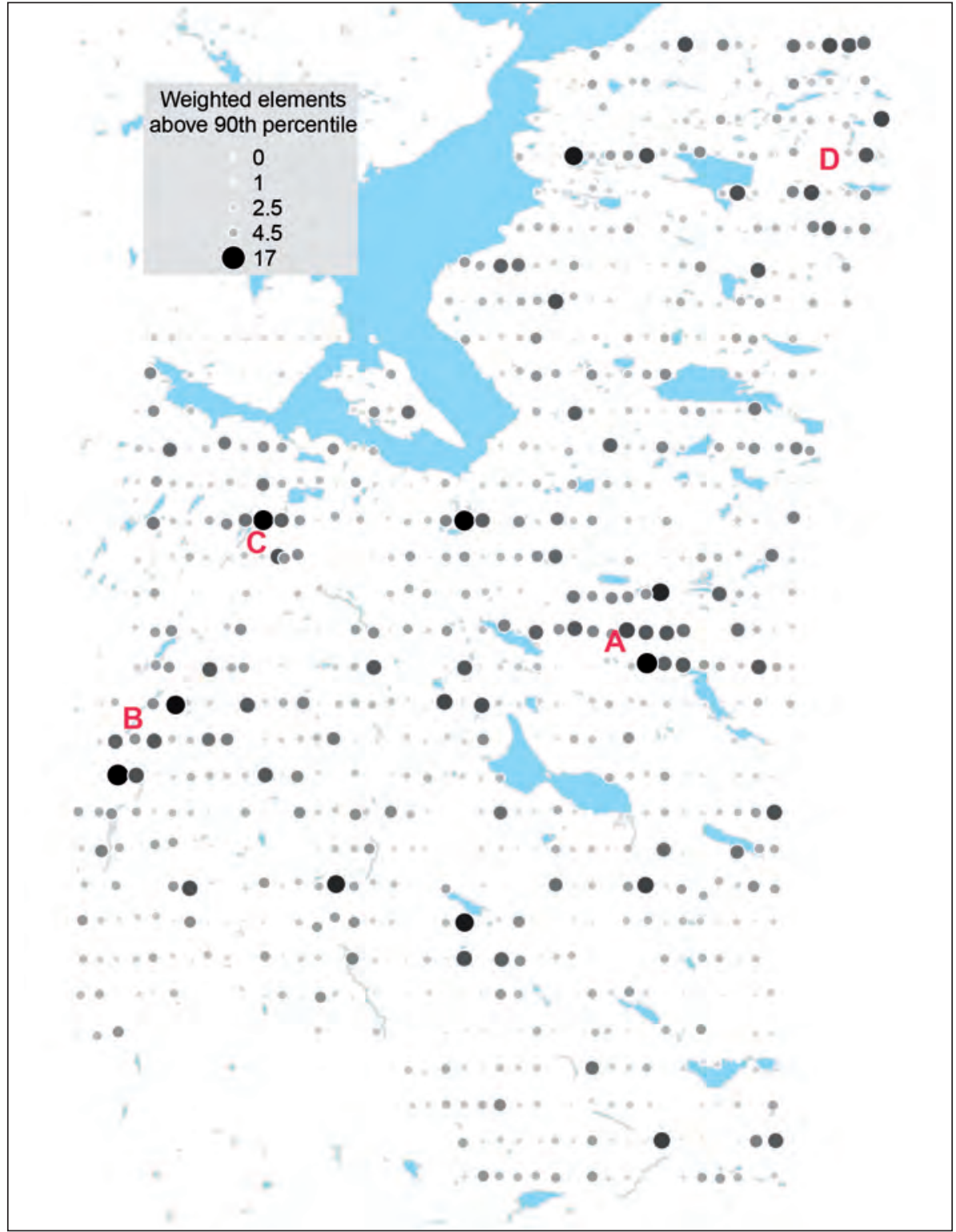

Figure 10. Multi-element plot for the area. The darker the symbol, the higher number of elements present in high concentrations. Letters A-D represent areas of interest.

magnetic field caused by changes in the concentrations of various magnetic minerals, while airborne electromagnetic surveys map the three-dimensional variation in conductivity caused by changes in mineralogy, intensity of alteration, water content or salinity. In order to eliminate displacements related to the dipping magnetic inclination of the Earth's field and centre anomalies directly over their sources (Baranov \& Naudy, 1964; Blakely, 1995), a reduction-to-pole (RTP) transformation was applied to the total-field aeromagnetic anomalies using the present-day Earth's field direction (Fig. 11A).

Ultramafic rocks typically have high magnetic and very low gamma ray responses (Saad, 1969; Galbraith \& Saunders, 1983; McCafferty \& Van Gosen, 2009), and are also resistive. The total magnetic anomaly map (Fig. 11A) clearly coincides with the ultramafic bodies (Fig. 1) mapped within the KNC, as also shown by McCafferty \&
Van Gosen (2009) for an area in California. To emphasise anomalies related to magnetic sources near the surface, thus removing magnetic signals that originate from sources that lie deeper in the ground, a high-pass filter (HP) was applied to the RTP data (Fig. 11B). This still clearly emphasises the mapped ultramafic bodies. The analytical signal amplitude is independent of the direction of the magnetisation of the source and is related to the amplitude of magnetisation (Nabighian, 1972; Roest \& Pilkington, 1993). This technique, as applied to the total field data, helps in clearly displaying the extent of edges and contacts between the different magnetised bodies in the area. The mapped ultramafic bodies shown in the analytical signal map (Fig. 11C) are clearly associated with high-amplitude anomalies. Their signature, in the analytical signal, suggests that in some cases their extent is greater than that of the mapped surface exposure. Some of the smaller ultramafic bodies, however, appear to be 
Table 2. Summary of the geophysical signatures of the various formations mapped in the Hattfjelldal area.

\begin{tabular}{|c|c|c|c|c|c|c|c|}
\hline Geological formations & $\begin{array}{l}\text { Magnetic } \\
\text { anomaly }\end{array}$ & $\begin{array}{l}\text { EM anomaly } \\
\text { Conductivity }\end{array}$ & Thorium & Uranium & Potasium & Total counts & Ternary image \\
\hline Ordovician granite & low & low & high & high-median & high-median & high & bright-green \\
\hline Gabbro & low & low & low & low & low & low & $\begin{array}{l}\text { dark: K higher } \\
\text { than Th }\end{array}$ \\
\hline Ultramafic & high pos. and neg. & low & low & low & low & low & dark \\
\hline Felsic metavolcanics & low & median & low & low & low & low & $\begin{array}{l}\text { magenta: } \mathrm{K}, \mathrm{U} \\
\text { higher than Th }\end{array}$ \\
\hline Mica schist, Mica gneiss & low & low & high - low & high - low & high - low & high - low & $\begin{array}{l}\text { bright yellowish - } \\
\text { dark magenta }\end{array}$ \\
\hline Phyllites & low - median & low & low & low & low & low & dark \\
\hline Phyllites with Graphite & low - median & high & median-high & median-high & median-high & median-high & bright \\
\hline Greenstone & low & median-low & low & low & low & low & $\begin{array}{l}\text { magenta: } \\
\text { low in } \mathrm{Th}\end{array}$ \\
\hline Calcareous, mica schist & low & low & low - median & low - median & low - median & low - median & yellowish- dark \\
\hline Granite & low & low & high & high & high & high & $\begin{array}{l}\text { bright: } \\
\text { higher in Th }\end{array}$ \\
\hline Marble & low & low & low & low & low & low & dark \\
\hline
\end{tabular}

too small to be detected, because of the relatively poor spatial resolution of the survey data, meaning they may be located between flight lines. The Hattli anomaly, on the other hand, shows no clear magnetic signal.

In addition to the well-defined ultramafic bodies, some irregular, elongated anomalies occur east of Skinnfjellet, trending generally N-S. These anomalies are also present on the high-pass filtered data (Fig. 11B). The anomalies lie between the solid and stippled lines in Fig. 1 that mark the boundary between the HNC and KNC. These coincide with observed iron formations, which gives reason to believe that these anomalies reflect some of the already investigated mineralisations, but also other mineralisations that have not yet been reported or discovered. There are also a few isolated magnetic anomalies which are not yet linked to a mapped geological formation, but could most likely be caused by small, subsurface, satellite ultramafic bodies.

The Frequency Domain Electromagnetic (FDEM) method provides a measure of the apparent electrical conductivity of the subsurface materials (Fig. 11D), employing instruments that take multiple frequency measurements at a fixed intercoil separation. The best results are achieved when searching for a conductive layer in a resistive medium. Areas with high conductivity in the Hattfjelldal area are mainly related to graphitebearing phyllites.

\section{Radiometric data}

Airborne gamma-emitting radiometric measurements estimate the naturally emitted gamma radiation residing in soils and rocks located within the upper $30-50 \mathrm{~cm}$ of the Earth's surface. In areas of bedrock terrain, gamma ray response therefore correlates broadly with major geological units. The intensity of the emitted radiation is proportional to the quantity of the main radio isotopes (K-U-Th) within the surface bedrock or overburden. Variation within these units can correspond to lithological variation and different styles of in situ weathering, which reflect the underlying lithology and geomorphic processes (Wilford et al., 1997).

$\mathrm{K}$ is a major constituent of many rock types and comprises about $2 \%$ of the Earth's crust. K-bearing minerals include feldspars and micas. On the other hand, $\mathrm{U}$ and $\mathrm{Th}$ are minor ingredients of the Earth's crust and average 2.5 and $9 \mathrm{mg} / \mathrm{kg}$, respectively (Gunn et al., 1997). Uranium occurs in U-oxide and in U-silicate minerals, while Th is typically found in allanite, monazite, xenotime and zircon. Generally, as the silica content of a rock increases, so do the radioelement concentrations.

Measured $\mathrm{K}$ directly corresponds to the isotopic decay peak for ${ }^{40} \mathrm{~K}$, as the potassium emits gamma rays during further decay to ${ }^{40} \mathrm{Ar}$. The calculation of Th and $\mathrm{U}$ concentrations is more complex since ${ }^{232} \mathrm{Th}$ and ${ }^{238} \mathrm{U}$ decay through A series of daughter nuclides until they reach stable $\mathrm{Pb}$ isotopes. Distinct emission peaks associated with ${ }^{208} \mathrm{Tl}$ and ${ }^{214} \mathrm{Bi}$ are used to calculate the abundance of $\mathrm{Th}$ and $\mathrm{U}$, respectively (Minty, 1997). Therefore, $\mathrm{U}$ and Th are usually expressed in equivalent parts per million $(\mathrm{eU}$ and eTh). This infers that the concentrations are from daughter elements in their decay chain (Wilford et al., 1997).

A Ternary image consists of colours generated from the relative intensities of the three components and represents subtle variations in the ratios of the three bands. Integrating gamma ray imagery with digital elevation models (Fig. $12 \mathrm{~A}-\mathrm{D}$ ) enables the distribution of radioelements to be interpreted in a landscape context. The integrated images 


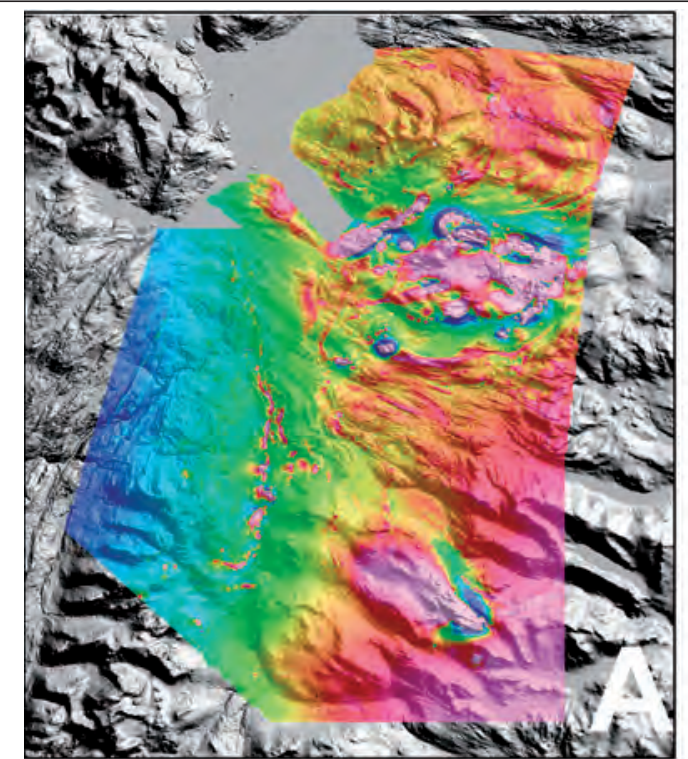

Total Magnetic Field, RTP (nT)
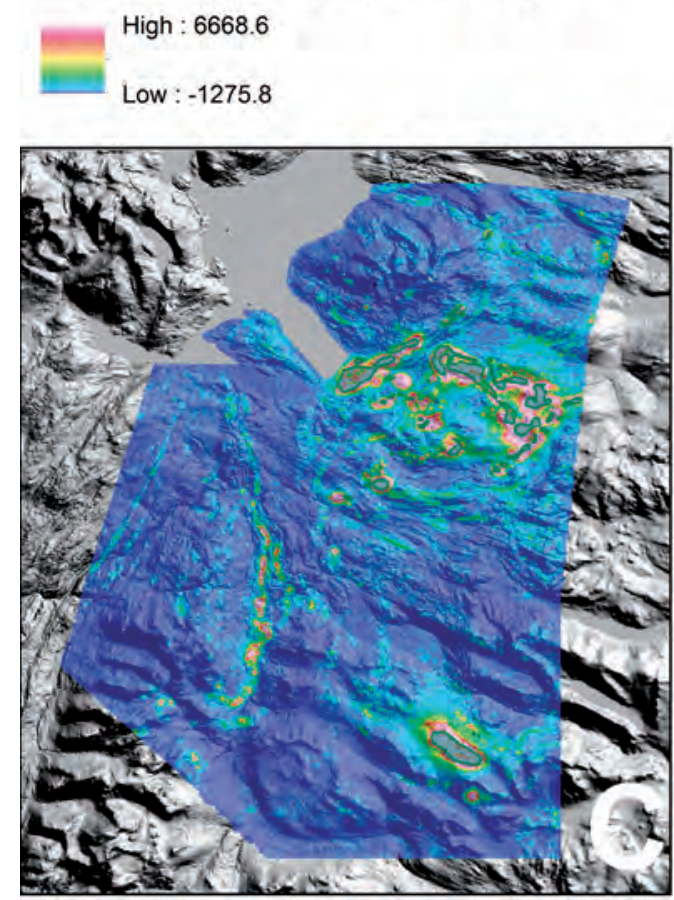

Total Field Anomaly, AS

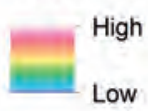

Ultramafic bodies

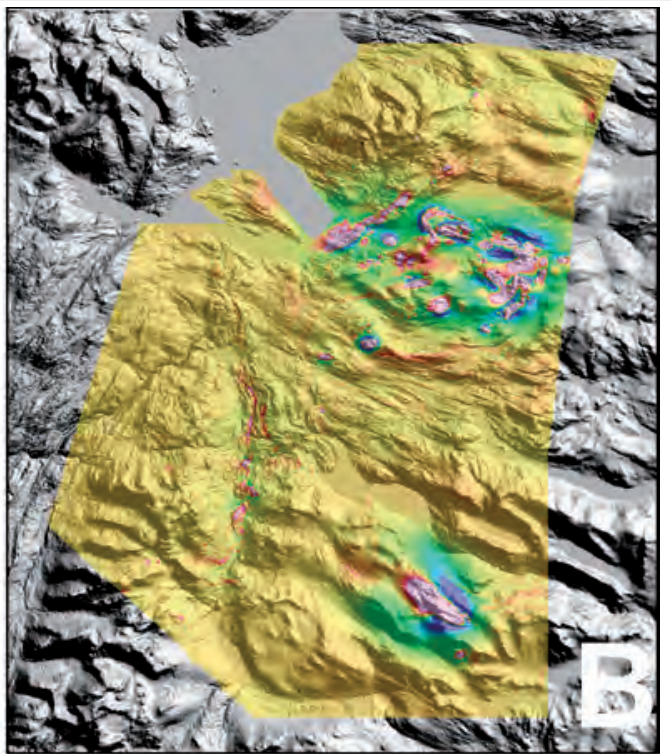

Total Field Anomaly, RTP, HP (nT)
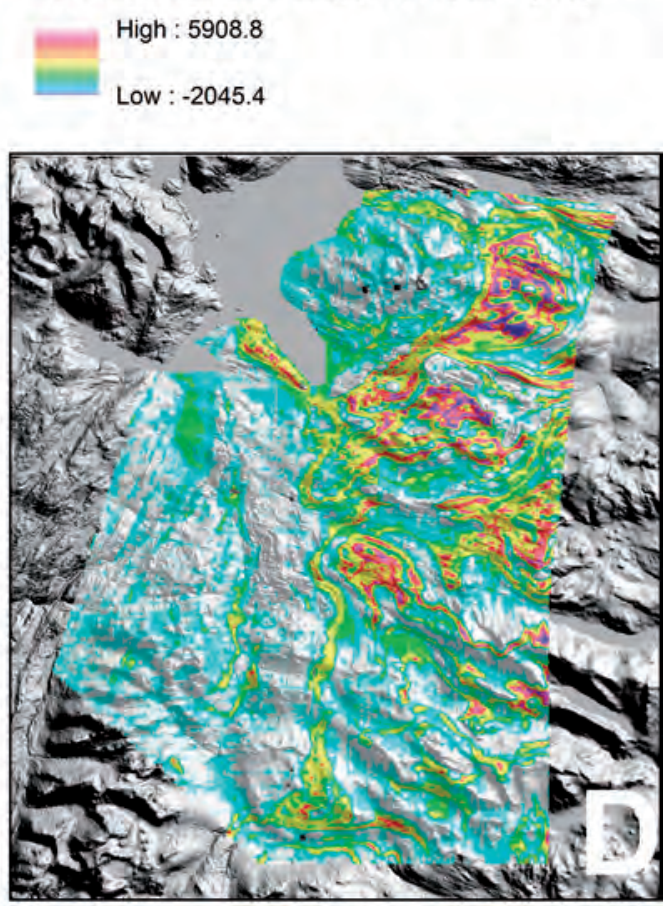

$\mathrm{EM} 980 \mathrm{~Hz}$ (App. Conductivity)
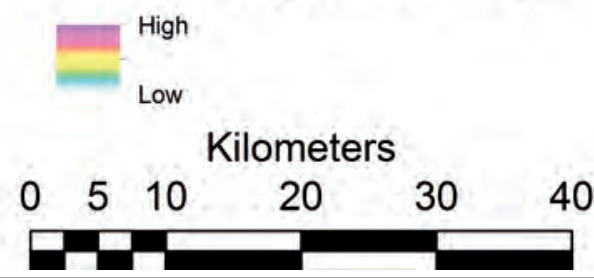

Figure 11. Geophysical data. (A) Total-field aeromagnetic anomalies with a reduction-to-pole (RTP) transformation, using the present-day Earth's field direction. (B) RTP data applied with a high-pass filter (HP). (C) The analytic signal amplitude is here independent of the direction of the magnetisation of the source and is related to the amplitude of magnetisation. (D) Map presenting the Frequency Domain Electromagnetic (FDEM) method, conductivity for the $980 \mathrm{~Hz}$ frequency.

allow for accurate geographic positioning and, as such, are useful for field interpretation (Wilford et al., 1997). The magnetite-rich ultramafic bodies appear darker than the surrounding units, indicating lower concentrations in $\mathrm{K}, \mathrm{eU}$ and $\mathrm{eTh}$. The white areas in the ternary image are an indication of high concentrations of all three elements. 


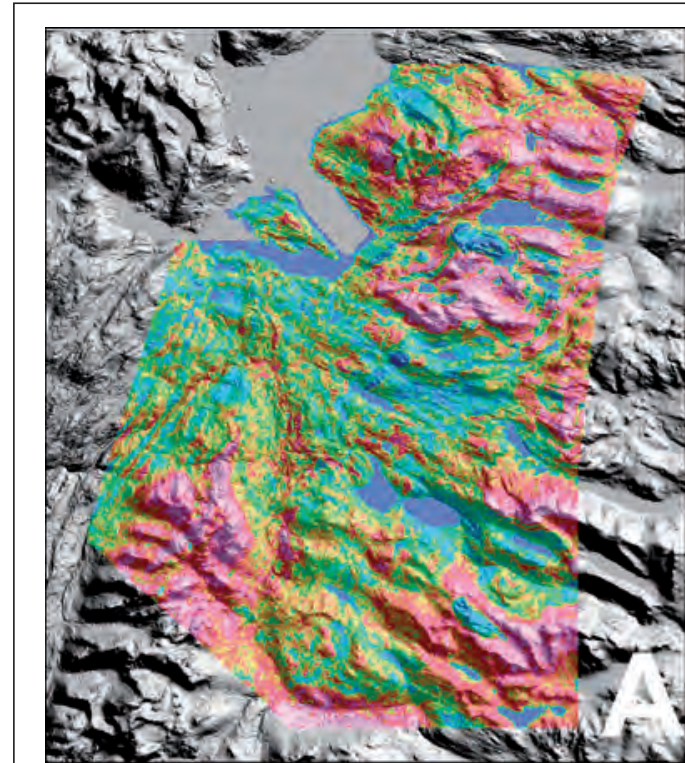

Potassium ground concentration (\%)
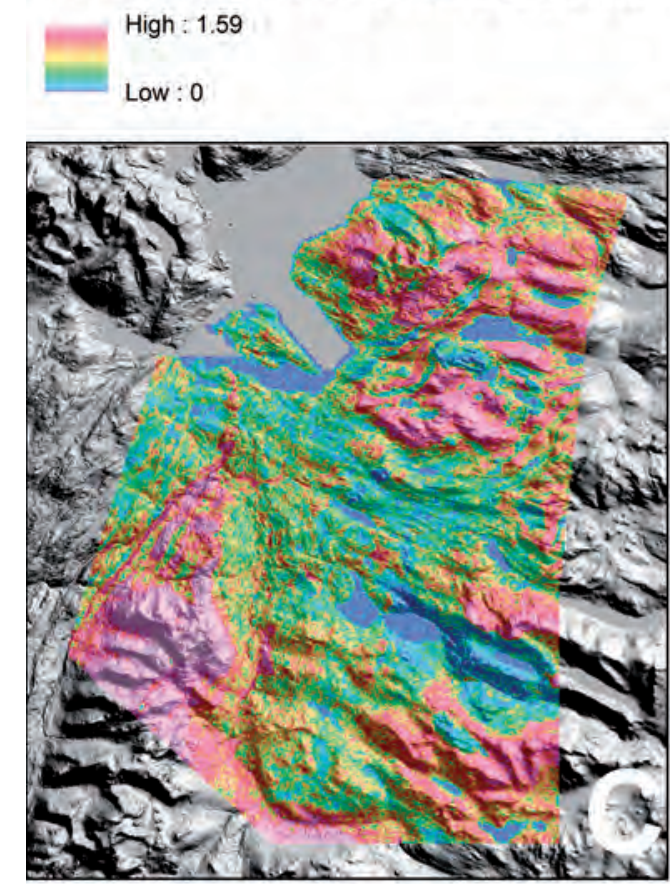

Thorium ground concentration (ppm)

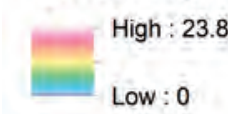

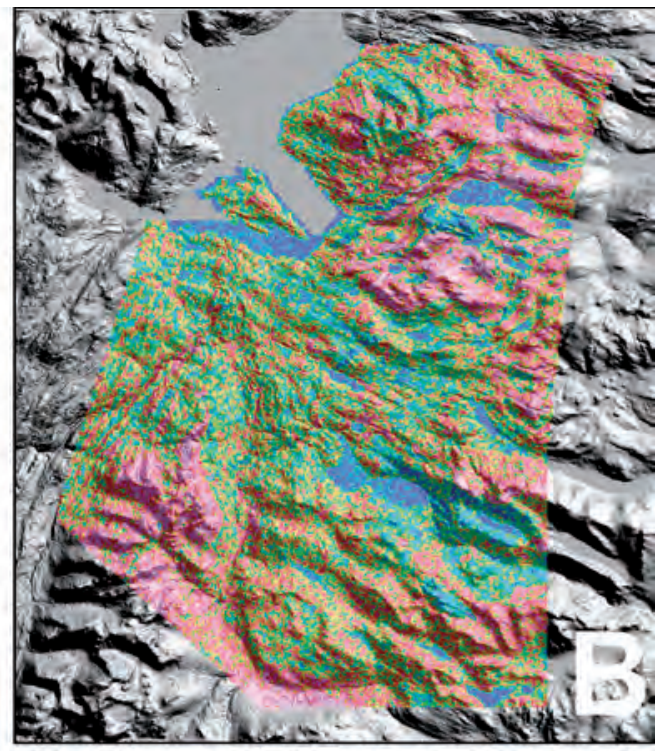

Uranium ground concentration (ppm)
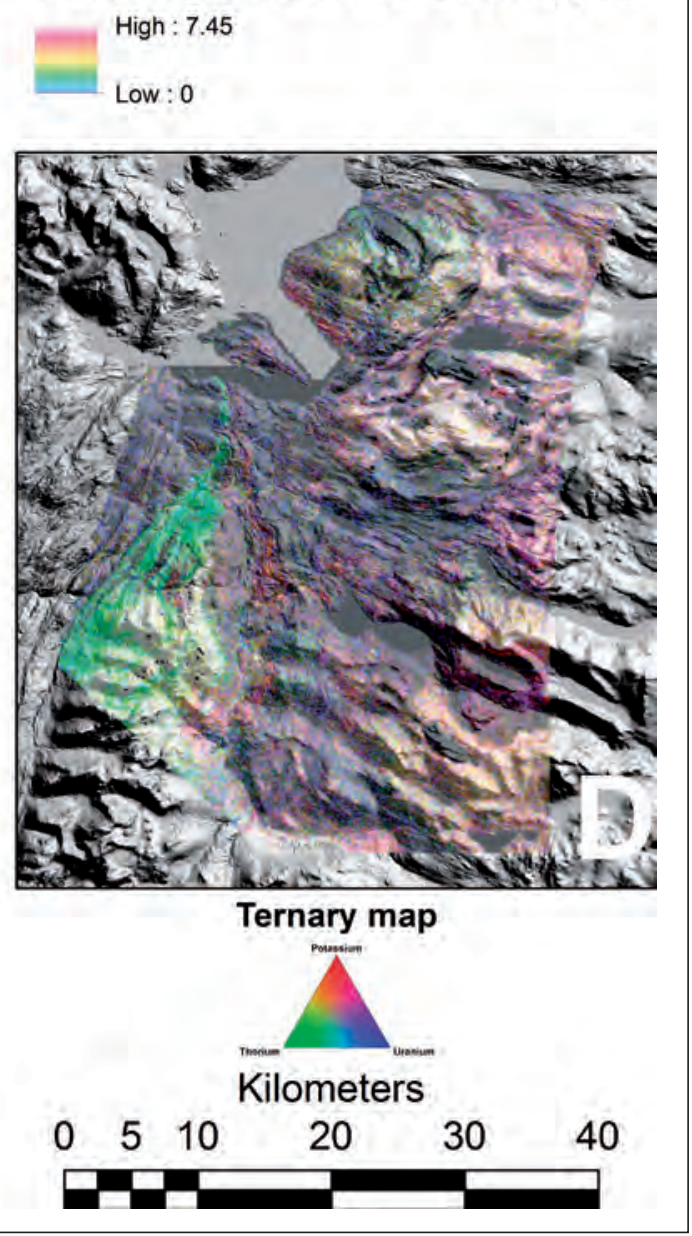

Figure 12. Radiometry results for elementary concentrations in (A) potassium (K), (B) uranium (eqU) and (C) thorium (eqTh). (D) Ternary image of the radiometry data. Potassium is assigned red, uranium blue and thorium green.

The magenta colour shows areas of high $\mathrm{K}$ and eU but low eTh concentrations, while the yellow indicates areas of high $\mathrm{K}$ and $\mathrm{eTh}$ but low eU concentrations.
The most noticeable features of the radiometric maps (Fig. 12A-D) are the high-amplitude anomalies correlated with the Ordovician granite suite of the Helgeland Nappe 


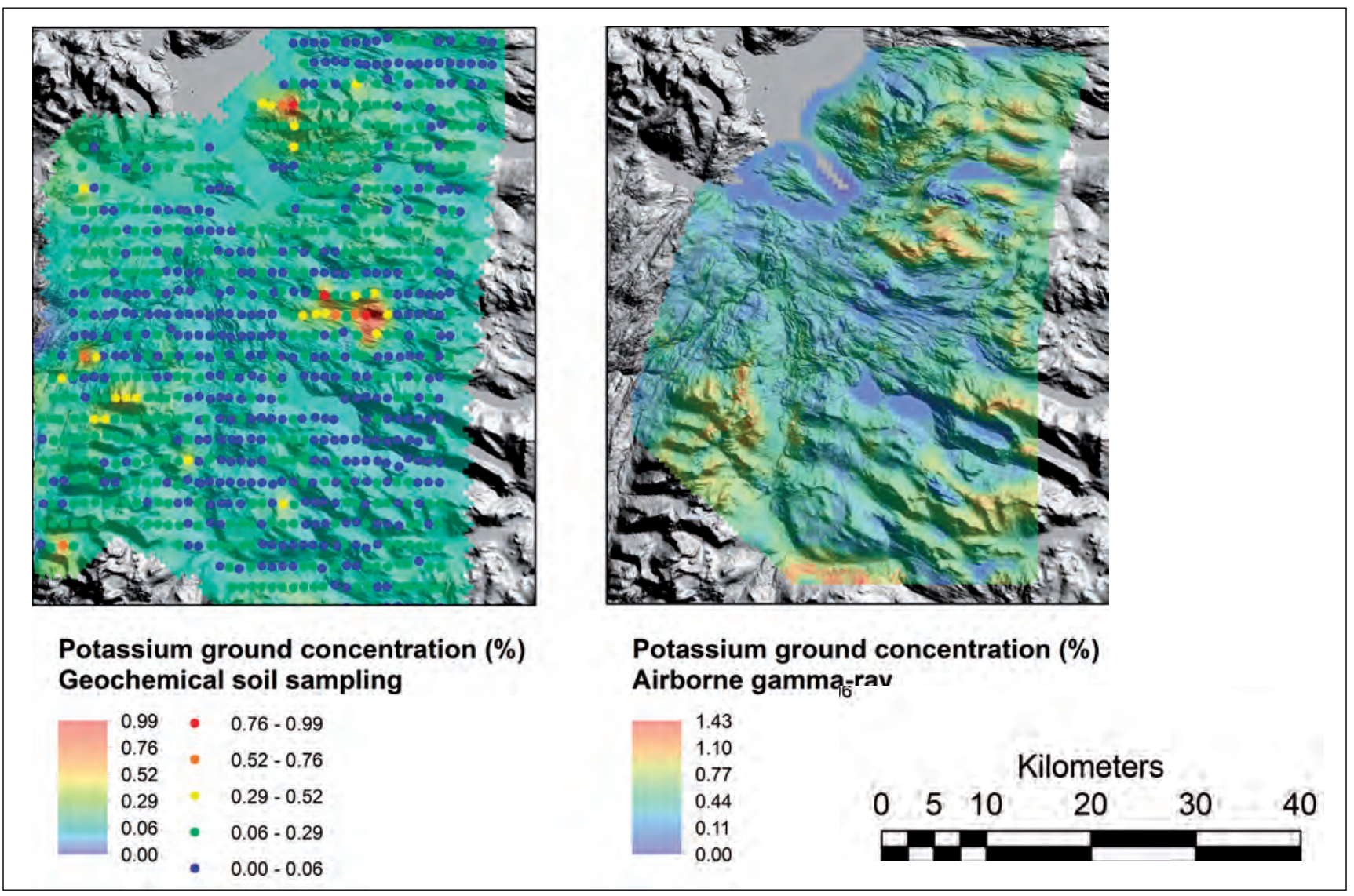

Figure 13. Concentrations of $K$ derived from chemical analysis of soil and radiometric methods.

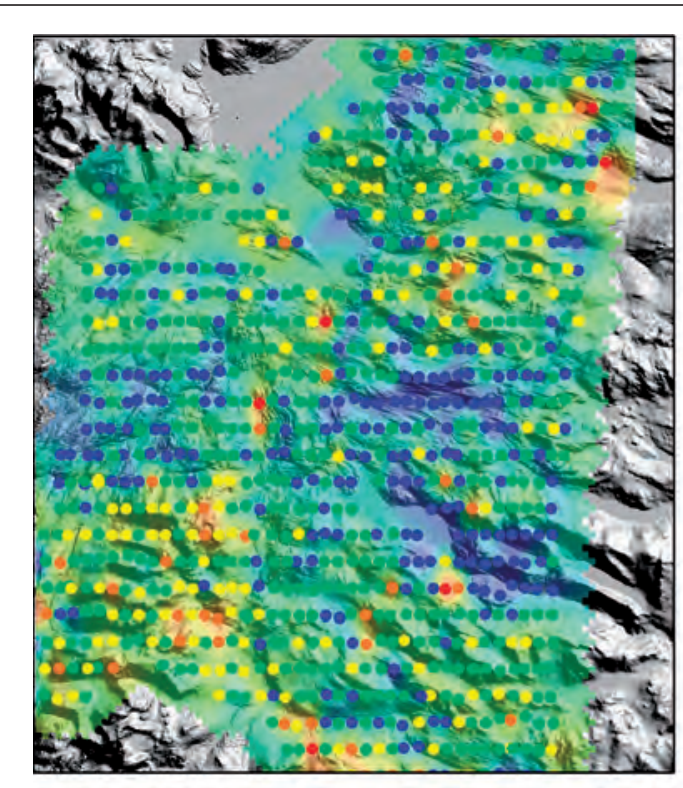

Thorium ground concentration (ppm) Geochemical soil sampling

$\begin{array}{lll}16.16 & \bullet & 12.87-15.37 \\ 12.87 & \bullet & 9.58-12.87 \\ 9.58 & \bullet & 6.29-9.58 \\ 6.29 & \bullet & 3.00-6.29 \\ 3.00 & - & 0.00-3.00 \\ 0.00 & \end{array}$

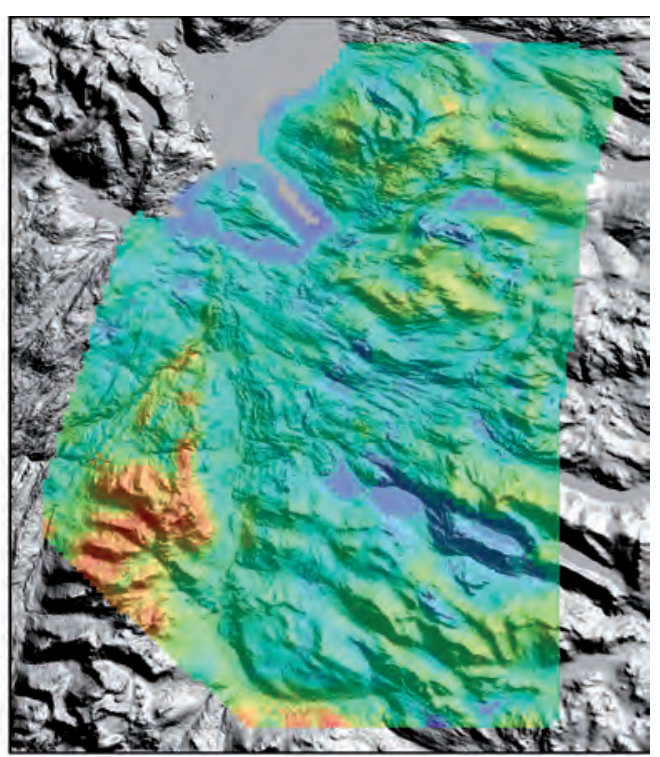

Thorium ground concentration (ppm) Airborne gamma-ray

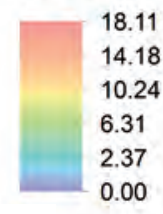

Figure 14. Concentrations of Th derived from chemical analysis of soil and radiometric methods. 


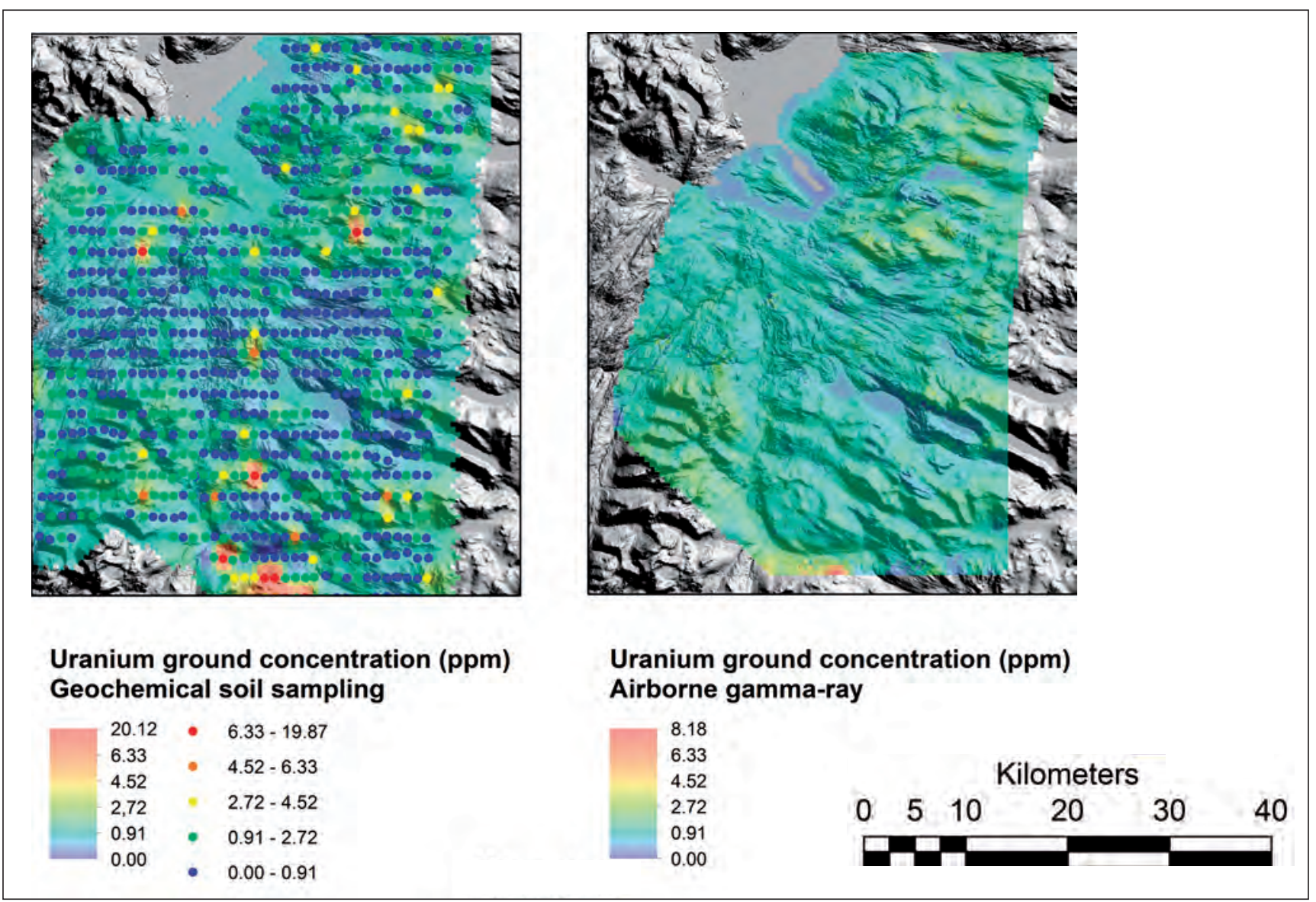

Figure 15. Concentrations of $U$ derived from chemical analysis of soil and radiometric methods.

Complex exposed on Skinnfjellet. Their high eTh contents suggest that the granite plutons likely formed as melts of enriched, garnet-amphibolite facies, plateau basalt crust subcreted beneath a convergent margin, rather than from depleted mid-ocean ridge basalt (MORB)-like crust (Foley et al., 2002; Kerrich et al., 2005). The granites are characterised by bright green colours in the ternary map (Fig. 12D). The mica schist formation of Skinnfjellet is also characterised by bright colours on the ternary map.

Gabbros at Krutfjellet have similar geophysical responses to the ultramafic rocks. However, their K content is relatively higher than eTh, compared to the ultramafics. Generally, mica schist and calcareous schist are characterised by bright yellowish colours in the ternary image (Fig. 12D), an indication of high concentrations of $\mathrm{K}$ and eTh but less eU. In some cases, the mapped formations of these rock types are shown with dark magenta colours in the ternary map, which could be interpreted as relating to a change in their geochemistry.

\section{Geophysical data related to geochemistry}

The sampling interval of the geophysical survey was considerably narrower than that of the geochemical soil sampling. In order to make a direct comparison of geo- chemical and geophysical data, both datasets were gridded to a common grid interval of 500 m. Figs. 13 (K),14 (eTh) and $15(\mathrm{eU})$ show the ground concentrations derived from the two methods over the same area.

Generally, there is a good relationship between them, especially for eTh (Fig. 14), meaning that their anomaly patterns have a lot of similarities. However, airborne eU, eTh and K concentrations are poorly correlated with soil measurements. Soil samples are taken from a single point, whereas in airborne spectrometry the gamma rays are summed over a circle with a radius of about 200 $\mathrm{m}$ over the point of measurement (Minty, 1997). This means that the calculated value for this point is an average of responses from diverse geological formations, most of which comes from the ground directly under the sensor and gradually reduces outwards in that circle. The estimated concentrations from the soil samples could be smaller or higher than those estimated from the gamma rays, but are still statistically related.

The best correlation is between soil and airborne eTh measurements (Fig. 14). High ground concentrations of $\mathrm{K}$ estimated from soil samples over Hattli are not observed on the airborne gamma ray K map (Fig. 13), which might be due to the thick overburden of bog within the area that masks signals from the bedrock. 


\section{Conclusions}

A well-defined multi-element anomaly is present in the Hattli area. The samples within the area show high concentrations of $\mathrm{Al}, \mathrm{Ba}, \mathrm{Be}, \mathrm{Ca}, \mathrm{Co}, \mathrm{Fe}, \mathrm{Ga}, \mathrm{K}, \mathrm{Mg}, \mathrm{Mn}, \mathrm{P}, \mathrm{Rb}$, $\mathrm{Sr}, \mathrm{Ti}, \mathrm{V}$ and $\mathrm{Zn}$, and low concentrations of $\mathrm{Cs}, \mathrm{Pb}, \mathrm{U}, \mathrm{Th}$, $\mathrm{Zr} \mathrm{Pb}$ and As. The source for the anomaly is unknown and not evident on the geophysical maps.

Data analysis of the geochemical results also defines other areas that show a geochemical signal. These are areas that potentially should be followed up through higher-density geochemical sampling or geological mapping.

Periglacial sediments have proven to be easily accessible sampling media that geochemically provide comparable results to the traditional. preferred sampling medium -the $\mathrm{C}$-horizon within a podzol profile.

The ultramafic bodies that have been mapped in the area are very well displayed in the magnetic data, but are not reflected as clear chemical patterns in the Quaternary sediment geochemistry. The weak correlation between the ultramafic rocks and expected high concentrations of, e.g., chromium and nickel is probably partly due to the low-density geochemical sampling in relation to the size of the ultramafic bodies, as well as the lack of soil development.

The magnetic data also define thin belts that are highly magnetic and are interpreted to coincide with iron deposits within that particular area. A comparison between airborne geophysics and geochemistry shows that thorium displays a good correlation between the results from chemical analyses in soil and from radiometric data.

Acknowledgements. First of all, the study would not have succeeded without the help from the other samplers: Atle Dagestad, Tor Erik Finne, Belinda Flem, Guri Ganerød, Åse Minde, Magnus Nicolaisen, Iselin Esp Pettersen, Gaute Storrø, Hild Sissel Skistad Thorsnes and Ola Vikhammer. Clemens Reimann and Rolf Tore Ottesen provided us with useful comments and interesting discussions. Iain Henderson corrected the English. The authors also wish to thank the reviewers David B. Smith and Eric Grunsky, who gave suggestions that improved the manuscript.

\section{References}

Aitchison, J. 1986: The statistical analysis of compositional data. Chapman and Hall, London, UK, 416 pp.

Albanese, S., De Vivo, B., Lima, A. \& Cicchella, D. 2006: Geochemical background and baseline values of toxic elements in stream sediments of Campania region (Italy). Journal of Geochemical Exploration 93, 21-34.

Anderson, R.S. \& Anderson, S.P. 2010: Geomorphology. The mechanisms and chemistry of landscapes. Cambridge University Press, Cambridge, 637 pp.
Baranov, V. \& Naudy, H. 1964: Numerical calculation of the formula of reduction to the magnetic pole. Geophysics 29, 67-79. doi:10.1190/1.1439334.

Bargel, T., Huhta, P., Johansson, P., Lagerbäck, R., Mäkinen, K., Nenonen, K., Olsen, L., Rokoengen, K., Svedlund, J.-O., Väänänen, T. \& Wahlroos, J.-E. 1999: Maps of Quaternary geology in Central Fennoscandia, sheet 3: Ice-flow Indicators, scale 1:1,000,000, and Quaternary stratigraphy, scale 1:2,000,000, Geological Surveys of Finland (Espoo), Norway (Trondheim) and Sweden (Uppsala).

Barkey, L.A. 1977: Hattfjelldals geologi. Abstract, Norsk geologisk forenings landsmøte 6-7. January, OSLO, NORWAY.

Blakely, R.J. 1995: Potential theory in gravity and magnetic applications. Cambridge University Press, Cambridge, England, 464 pp.

Chambers, J.M., Cleveland, W.S., Kleiner, B. \& Tukey P.A. 1983: Graphical methods for data analysis. Wadsworth International Group, Duxbury Press, Boston, 336 pp.

Corneliussen, O.A. 1891: Bidrag til kundskapen on Nordland amts geologi. Norges geologiske undersøkelse Publication 4, 149-186.

Dallmann, W.K. 1987: Structural, stratigraphical and sedimentological investigations in the Caledonian Upper Köli Nappes of the Hattfjelldal area, Nordland, Norway. Dr. Scient. thesis, University of Oslo, $181 \mathrm{pp}$.

Dallmann, W.K. 1994: Hattfjelldal, bedrock geology map 1926 II, scale 1:50,000, Norges geologiske undersøkelse.

Dallmann, W.K. \& Stølen, L.K. 1994: Hattfjelldal - berggrunnsgeologisk kart 1926 II - M, scale 1:50,000. Beskrivelse. (In Norwegian with English summary). Norges geologiske undersøkelse Report 93.044, $47 \mathrm{pp}$

Demetriades, A. 2011: Understanding the Quality of Chemical Data from the urban environment - Part 2: Measurement Uncertainty in the Decision-making Process. In Johnson, C.C., Demetriades, A., Locutura, J. \& Ottesen, R.T. (eds.): Mapping the Chemical Environment of Urban Areas, Wiley-Blackwell, Oxford, UK, 616 pp.

Eggen O.A. \& Finne T.E. 2014: Geochemical data from Hattfjelldal. Norges geologiske undersøkelse Report 2014.053, 77 pp.

Eilu, P., Bergman, T., Bjerkgård, T., Feoktistov, V., Hallberg, A., Korsakova, M., Krasotkin, S., Muradymov, G., Nurmi, P.A., Often, M., Perdahl, J.-A., Philippov, N., Sandstad, J.S., Stromov, V. \& Tontti, M. 2009: Metallogenic Map of the Fennoscandian Shield, scale 1:2,000,000, Geological Survey of Finland, Geological Survey of Norway, Geological Survey of Sweden, The Federal Agency of Use of Mineral Resources of the Ministry of Natural Resources and Ecology of the Russian Federation. http://tupa.gtk.fi/kartta/erikoiskartta/ ek_080_300dpi.pdf (accessed 13.11.2015).

Ellefsen, K.J., Smith, D.B. \& Horton, J.D. 2014: A modified procedure for mixture-model clustering of regional geochemical data. Applied Geochemistry 51, 315-326.

Filzmoser, P. 2013: StatDA: Statistical Analysis for Environmental Data. $\mathrm{R}$ package version 1.6.7. https://cran.r-project.org/web/packages/ StatDA/index.htm (accessed 13.11.2015)

Filzmoser, P., Hron, K. \& Reimann, C. 2009: Univariate statistical analysis of environmental (compositional) data: Problems and possibilities. Science of the Total Environment 407, 6100-6108.

Finne, T.E. \& Eggen, O.A. 2013: Soil geochemical data from NordSalten, Nordland. Norges geologiske undersøkelse Report 2013.015, $101 \mathrm{pp}$.

Foley, S., Tiepolo, M., Vannucci, R. 2002: Growth of early continental crust controlled by melting of amphibolite in subduction zones. Nature 417, 837-840. 
Galbraith, J.H. \& Saunders, D.F. 1983: Rock classification by characteristics of aerial gamma-ray measurements. Journal of Geochemical Exploration 18, 47-73.

Gjelle, S.T., Marker, M., Solli, A. \& Gustavson M. 2003: Røssvatnet, bedrock geology map1928 - I, scale 1:50,000, Norges geologiske undersøkelse.

Goldhaber, M.B., Morrison, J.M., Holloway, J.M., Wanty, R.B., Helsel, D.R. \& Smith, D.B. 2009: A regional soil and sediment geochemical study in northern California. Applied Geochemistry 24, 1482-1499.

Grunsky, E.C., Drew, L.J. \& Sutphin, D.M. 2009: Process recognition in multi-element soil and stream-sediment geochemical data. Applied Geochemistry 24, 1602-1616.

Gunn, P.J., Minty, B.R.S. \& Milligan, P.R. 1997: The airborne gammaray spectrometric response over arid Australian terranes. In Gubins, A.G. (ed.): Proceedings of Exploration 97-4th Decennial International Conference on Mineral Exploration: Radiometric Methods and Remote Sensing, Paper 96, pp. 733-740.

Gustavson, M. 1981: Mosjøen, bedrock geology map, scale 1:250,000, Norges geologiske undersøkelse.

Holmsen, G. 1913: Oversikt over Hattfjelldalens geologi. Norges geologiske undersøkelse Publication 61, 1-34.

Hutcheson, G. \& Sofroniou, N. 1999: The multivariate social scientist: Introductory statistics using generalized linear models. Sage Publications, Thousand Oaks, CA, $288 \mathrm{pp}$.

Kaiser, H.F. \& Rice, J. 1974: Little Jiffy, Mark IV. Educational and psychological Measurement 34, 111-117.

Kerrich, R., Goldfarb, R.J. \& Richards, J. 2005: Metallogenic provinces in an evolving geodynamic framework: Economic Geology 100th Anniversary Volume, 1097-1136.

Kjeldsen, S. 1987: Geokjemisk kartlegging i Nordland og Troms. ICAPanalyse av løsmassenes finfraksjon. Norges geologiske undersøkelse Report 1987.142, 69 pp.

Le Maitre, R.W. 1982: Numerical petrology. Elsevier, Amsterdam, 281 pp.

McCafferty, A.E. \& Van Gosen, B.S. 2009: Airborne gamma-ray and magnetic anomaly signatures of serpentinite in relation to soil geochemistry, northern California. Applied Geochemistry 24, 15241537.

Minty, B. 1997: Fundamentals of airborne gamma-ray spectrometry. Australian Geological Survey Organisation Journal of Australian Geology and Geophysics 17, 39-50.

Moen, A. 1998: Nasjonalatlas for Norge: Vegetasjon. Statens kartverk, Hønefoss, 199 pp.

Mørk, M.B.E. 1979: Metamorf utvikling og gabbro-intrusjon på Krutfjell, Nordland. Cand. real. thesis, University of Oslo, 307 pp.

Mørk, M.B.E. 1985: Geology and metamorphism of the Krutfjellet mega-lens, Nordland. In Gee, D.G. \& Sturt, B.A. (eds.): The Caledonide orogen - Scandinavia and related areas, John Wiley \& Sons, Chichester, 1266 pp.

Nabighian, M.N. 1972: The analytical signal of two-dimensional magnetic bodies with polygonal cross-section: its properties and use for automated anomaly interpretation. Geophysics 7, 507-517.

NGU 2015: Mineral deposits database. Map version. http://geo.ngu.no/ kart/mineralressurser/ (accessed March 2015).

Oxaal, J. 1911: Fra indre Helgeland. Fjeldbygningen og bergartene samt bemerkninger om bergverksdriften. Norges geologiske undersøkelse Publication 59, 65 pp.

R Core Team 2014: R: A Language and Environment for Statistical Computing, R Foundation for Statistical Computing, Vienna, Austria. http://www.R-project.org/(accessed 13.11.2015)
Reimann, C. \& Melezhik, V. 2001: Metallogenic provinces, geochemical provinces and regional geology - what causes large-scale patterns in low density geochemical maps of the C-horizon of podzols in Arctic Europe? Applied Geochemistry 16, 963-983.

Reimann, C. \& Garrett, R.G. 2005: Geochemical background - concept and reality. Science of the Total Environment 350, 12-27.

Reimann, C., Filzmoser, P. \& Garrett, R.G. 2002: Factor analysis applied to regional geochemical data: problems and possibilities. Applied Geochemistry 17, 185-206.

Reimann, C., Filzmoser, P., Garrett, R. \& Dutter, R. 2008: Statistical data analysis explained. Applied environmental statistics with $R$. John Wiley\& Sons, Chichester, UK, 343 pp.

Reimann, C., Finne, T.E. \& Filzmoser, P. 2011: New geochemical data from a collection of till samples from Nordland, Troms and Finnmark. Norges geologiske undersøkelse Report 2011.45, 152 pp.

Reimann, C., Finne, T.E. \& Filzmoser, P. 2012: Soil geochemical data from the Nordkinn peninsula, Finnmark. Norges geologiske undersøkelse Report 2012.016, 95 pp.

Reimann, C., Birke, M., Demetriades, A., Filzmoser, P. \& O'Connor, P. (eds.) 2013: Chemistry of Europe's Agricultural Soils, Part A: Methodology and interpretation of the GEMAS Data Set, Bundesanstalt für Geowissenschaften und Rohstoffe, Hannover, 528 pp

Reimann, C., Schilling, J., Roberts, D. \& Fabian, K. 2015: A regionalscale geochemical survey of soil $\mathrm{O}$ and $\mathrm{C}$ horizon samples in Nord-Trøndelag, Central Norway: Geology and mineral potential. Applied Geochemistry 61, 192-205.

Rekstad, J. 1924: Hattfjelldalen. Beskrivelse til den geologiske generale kart. Norges geologiske undersøkelse Publication 124, 1-36.

Rodionov, A., Ofstad, F., Stampolidis, A. \& Tassis, G. 2014: Helicopterborne magnetic, electromagnetic and radiometric geophysical survey in Hattfjelldal, Nordland County. Norges geologiske undersøkelse Report 2014.029, 29 pp.

Roest, W.R. \& Pilkington, M. 1993: Identifying remanent magnetization effects in magnetic data. Geophysics 58, 653-659.

Saad, A.H. 1969: Magnetic properties of ultramafic rocks from Red Mountain, California. Geophysics 34, 974-987.

Salminen, R. \& Tarvainen, T. 1997: The problem of defining geochemical baselines. A case study of selected elements and geological materials in Finland. Journal of Geochemical Exploration 60, 91-98.

Sandstad, J.S. \& Hallberg, A. 2012: N025 Grong-Stekenjokk Cu-Zn. In Eilu, P. (ed.): Mineral deposits and metallogeny of Fennoscandia, Geological Survey of Finland, Special Paper 53, 401 pp.

Stephens, M.B. 1980: Occurrence, nature and tectonic significance of volcanic and high-level intrusive rocks within the Swedish Caledonides. In Wones, D.R. (ed.): The Caledonides in the USA, Virginia Polytechnic Institute and State University, Department of Geological Sciences, Memoir 2, 289-298.

Stephens, M.B., Gustavson, M., Ramberg, I.B. \& Zachrisson E. 1985: The Caledonides of central-north Scandinavia - a tectonostratigraphic overview. In Gee D.G. \& Sturt B.A. (eds.): The Caledonide orogen - Scandinavia and related areas, John Wiley \& Sons Ltd., Chichester, pp. 135-162.

Strand, T. 1953: Geologiske undersøkelser i den sydøstlige del av Helgeland. Norges geologiske undersøkelse Publication 184, 124-141.

Strand, T. 1955: Sydøstlige Helgelands geologi. Norges geologiske undersøkelse Publication 191, 56-70.

Stølen, L.K. 1985: Et geologisk studium av solitere ultramafiske bergarter og omkringliggende metasedimenter og metavulkanitter tilhørende Kölidekkene i Krutådalsområdet, Hattfjelldal, Nordland 
- stratigrafi, deformasjon og metamorfose. MSc thesis, University of Oslo, 148 pp.

Tukey, J.W. 1977: Exploratory data analysis. Addison-Wesley, Reading, Massachussetts, USA, 689 pp.

Wilford, J.R., Bierwirth, P.N. \& Craig, M.A. 1997: Application of airborne gamma-ray spectrometry in soil/regolith mapping and applied geomorphology. Australian Geological Survey Organisation Journal of Australian Geology and Geophysics 17, 201-216.

Zhao, N. 2009: The Minimum Sample Size in Factor Analysis. https:// www.encorewiki.org/display/ nzhao/The+Minimum+Sample+Size + in+Factor+Analysis (accessed April 2015). 
